\title{
Response of stratification processes to tidal current alteration due to channel narrowing and deepening
}

\author{
Lei Zhu \\ Qing $\mathrm{He}$ \\ Jian Shen \\ Virginia Institute of Marine Science
}

Follow this and additional works at: https://scholarworks.wm.edu/vimsarticles

Part of the Oceanography Commons

\section{Recommended Citation}

Zhu, Lei; He, Qing; and Shen, Jian, Response of stratification processes to tidal current alteration due to channel narrowing and deepening (2020). Journal of Geophysical Research: Oceans, 125(2), e2019JC015223.

10.1029/2019JC015223

This Article is brought to you for free and open access by the Virginia Institute of Marine Science at W\&M ScholarWorks. It has been accepted for inclusion in VIMS Articles by an authorized administrator of W\&M ScholarWorks. For more information, please contact scholarworks@wm.edu. 


\section{RESEARCH ARTICLE 10.1029/2019JC015223 \\ Key Points: \\ - Stratification is strongly enhanced \\ Response of Stratification Processes to Tidal Current Alteration due to Channel Narrowing and Deepening} by channel narrowing and deepening

- Lateral straining leads to maximal stratification during early ebb tide in the predeepened channel

- Boundary mixing diffusion controls the transverse salinity gradient under stratified circumstance

Correspondence to:

Q. He,

qinghe@sklec.ecnu.edu.cn

Citation:

Zhu, L., He, Q., \& Shen, J. (2020). Response of stratification processes to tidal current alteration due to channel narrowing and deepening. Journal of Geophysical Research: Oceans, 125, e2019JC015223. https://doi.org/ 10.1029/2019JC015223

Received 15 APR 2019 Accepted 7 JAN 2020

Accepted article online 17 JAN 2020

(C)2020. American Geophysical Union. All Rights Reserved.

\author{
Lei $\mathrm{Zhu}^{1,2,3}$, Qing $\mathrm{He}^{1}$, and Jian Shen ${ }^{4}$ \\ ${ }^{1}$ State Key Laboratory of Estuarine and Coastal Research, East China Normal University, Shanghai, China, ${ }^{2}$ School of \\ Marine Science, Sun Yat-sen University, Guangzhou, China, ${ }^{3}$ Guangdong Provincial Key Laboratory of Marine Resource \\ and Coastal Engineering, Guangzhou, China, ${ }^{4}$ Virginia Institute of Marine Science, College of William and Mary, \\ Williamsburg, VA, USA
}

\begin{abstract}
Stratification in estuaries has received much focus due to its importance in estuarine hydrodynamics and material transport. By utilizing a well-calibrated numerical model, in this work we investigate the changes in stratification in the deepened and narrowed North Passage of the Changjiang Estuary. Before channel narrowing and deepening, lateral straining, generated by the interaction between vertical shear in lateral flow and transverse salinity gradient, is the dominant factor that controls stratification. A two-layer structure of the lateral flow strains the isopycnal transversely, resulting in rapid stratification from late flood to early ebb tide. Thus, maximum stratification occurs during the early ebb. Then, the stratification was suppressed by the vertical mixing and the less stratified water advected from upstream, even the vertical shear in along-channel flow continued to strain the isopycnal. After channel deepening and narrowing, the salinity in the upper water column experienced a sharp vertical gradient during the entire tidal cycle, while the transverse salinity gradient and lateral flow are profoundly reduced. The impact of lateral straining on stratification becomes minor. The enhanced stratification results in a sharp decrease in turbulent mixing within the pycnocline. The water movement in the upper layer is in a free-stream status and the tidal current speed increases significantly. The alteration of the vertical current structure enhances the along-channel tidal straining and stratification is most vigorous on late ebb tide.
\end{abstract}

Plain Language Summary Waterway regulation and dredging have deepened and narrowed the estuaries around the world, altering hydrodynamics, salt intrusion, and sediment transport. Expensive dredging is carried out as these newly built navigation channels suffer heavy siltation. One of the major causes to sediment siltation is the turbulence suppression by stratification. The Changjiang Estuary provides a typical example to study how stratification processes responded to the alterations of tidal currents and density field after construction of a navigation channel. Prior to channel regulation, the water column experiences rapid stratification at the late stage of flood tide as isopycnals are strained by the lateral flow. The maximum stratification occurs during the peak ebb, and is destroyed by vertical mixing from late ebb to early flood. The upper water column of the main channel experienced permanent stratification as active mixing is constrained below the pycnocline after channel deepening. Both lateral flow and transverse salinity gradient decrease as a result of the enhanced stratification. The stratification is most vigorous during late ebb, which is a product of interaction between strong vertical shear in along-channel velocity and longitudinal salinity gradient.

\section{Introduction}

The stratification and destratification processes play key roles in estuarine systems. These processes are the leading factors that control the strength of estuarine circulation (Hansen \& Rattray, 1965), enhance sediment trapping (Geyer, 1993), affect the primary production (Field et al., 1998), and determine the periods and level of hypoxia (Kuo \& Neilson, 1987). Thus, understanding stratification processes and the controlling mechanisms is significant for estuarine science.

Simpson (1981) used the potential energy anomaly, which represents the energy required to cause complete mixing, to quantify stratification. Further, Simpson et al. (1990) discovered that stratification is mainly affected by the interaction between vertical shear of tidal current and along-channel salinity 
gradient at intratidal time scales, which enhances the stratification during the ebb tide and destratifies the water column during the flood tide. This process is known as tidal straining. By utilizing the time-dependent dynamic equation for potential energy anomaly, Burchard and Hofmeister (2008) noted that stratification in estuaries is controlled by the competition between tidal straining and vertical mixing.

In a real estuary, the hydrodynamics are always three-dimensional due to complex geometry and bathymetry. The stratification process cannot be fully explained by the conventional longitudinal and vertical tidal processes. Because of the lateral variation in transverse bathymetry, many estuaries exhibit spatial gradients in stratification between the channel and shoal. Due to the friction in shallow regions, the stratification over shoals is largely suppressed by turbulent mixing (Scully \& Freidrichs, 2007). When the lateral circulation is significant, the water exchange between the channel and shoal induced by lateral circulation would modify the stratification (Nepf \& Geyer, 1996). Similar to the along-channel straining, the interaction between the vertical shear induced by lateral flows and the lateral salinity gradient can also strain the isopycnal, thus affecting the stratification processes (Basdurak et al., 2013; Cheng et al., 2009). The lateral straining impact on stratification is vigorous during the late period of flood tide and even plays a more important role than along-channel straining that occurs during the spring tide (Becherer et al., 2015). Further study demonstrates that stratification/destratification is determined by three-dimensional tidal movement and salinity transport processes. The vertical salinity profile can be modified by along-channel and transverse straining, advection, and vertical mixing (Scully \& Geyer, 2012). Therefore, it is necessary to consider the three-dimensional dynamic processes when studying the stratification/destratification processes in estuaries.

Estuaries are subject to intensive human intervention due to their unique geophysical locations. Most of the geomorphological and physical changes began at the end of 19th Century and have increased rapidly to the present (Perillo et al., 2005). To accommodate rapid economic development, many estuaries were trained to improve the navigability. Dredging activities have deepened estuaries around the world, which results in consequent changes in tidal amplitude, salt intrusion, estuarine circulation, and sediment transport. For example, tidal range has increased by $1.5 \mathrm{~m}$ in the Ems Estuary after the channel was deepened from 4-5 to $7 \mathrm{~m}$ (Chernetsky et al., 2010). In the Cape Fear River Estuary, tropical cyclone making landfall today will produce significantly higher surge after channel deepening (Familkhalili \& Talke, 2016). The deepening of Newark Bay has led an increase in horizontal salinity gradient and a doubling of the estuarine exchange flow (Chant et al., 2018). The changed estuarine hydrodynamics further caused adaptations in sediment transport, e.g., increase in turbidity and migration of turbidity maximum zone (de Jonge et al., 2014; Winterwerp, 2011). The Changjiang Estuary is also a typical example, where the construction of a navigation channel has significantly modified the stratification, estuarine circulation, and sediment transport. The regulated North Passage was narrowed as a result of training walls and groins (Figure 1a). The water column became stratified as dense, salty water intrudes near the bottom in the deeper part of the channel (Niroomandi et al., 2018). The stratification also led to an increase in the two-layer estuarine circulation in the lower reach of the North Passage (Jiang et al., 2012). Moreover, the altered estuarine circulation benefits faster transport of freshwater in the upper water column and trapping the river-borne sediment near the bottom (Wang et al., 2010). The change in estuarine circulation also altered the sediment transport and associated erosion and deposition within the estuary (Pan et al., 2012).

Although the change in estuarine hydrodynamics associated with engineering works has been extensively studied, the mechanism that leads to such changes has not yet been fully understood. Most studies in the North Passage still focus on the two-dimensional (longitudinal and vertical) estuarine dynamic processes, while the impact of lateral flows was largely overlooked. In this study, we aim to investigate the change in stratification processes and its controlling mechanism. We hypothesize that the stratification is affected by both the along-channel and lateral tidal flows. We applied a numerical model with different bathymetries before and after the engineering works to study the change in tidal dynamics and to investigate the leading-order controlling factors of the stratification alternation. The objectives are (1) to quantify the alteration of stratification in the North Passage of the Changjiang Estuary; (2) to evaluate the impact of lateral flows on stratification; and (3) to demonstrate the relative importance of tidal straining, advection, and vertical mixing on density stratification. 


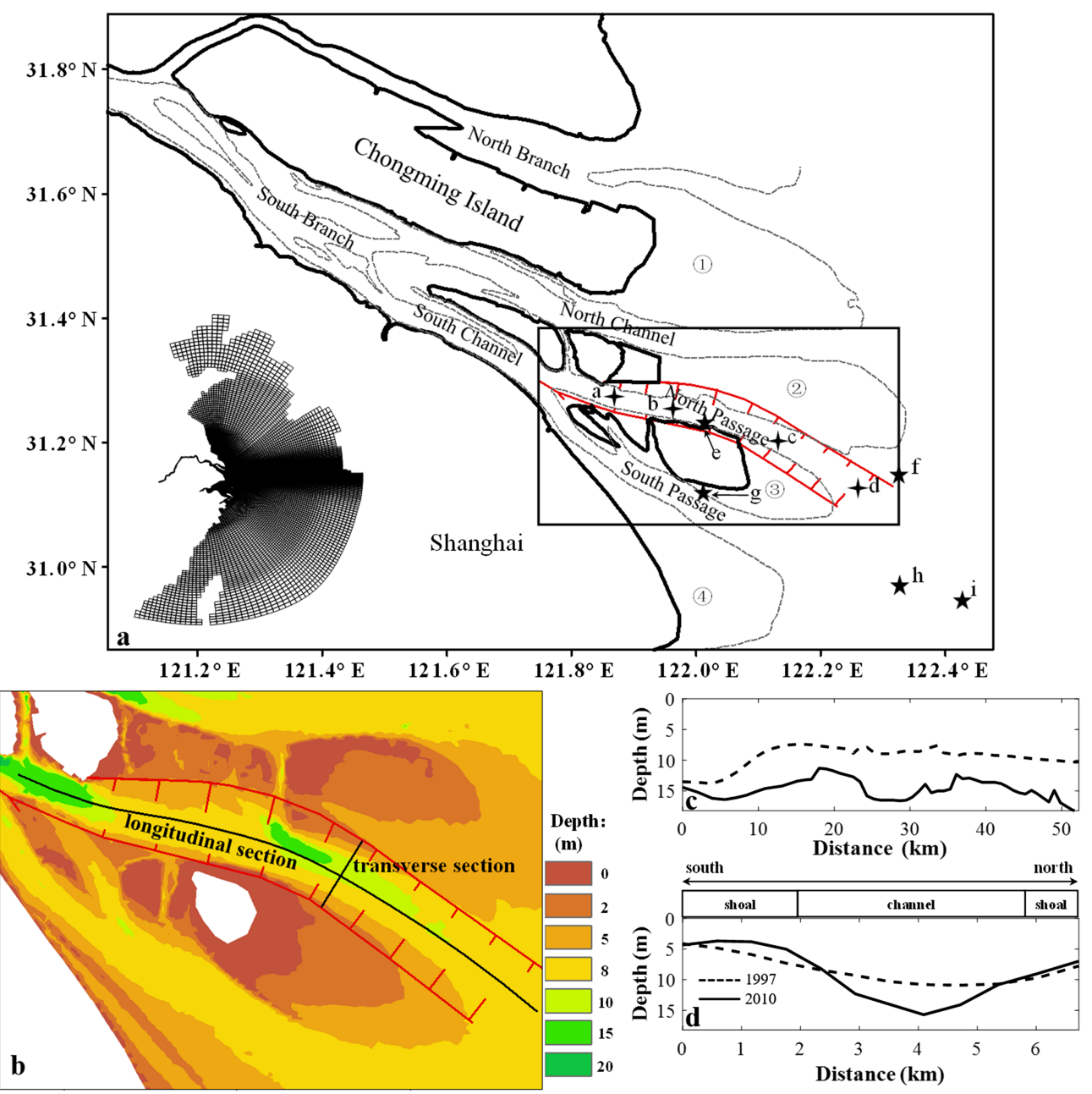

Figure 1. (a) Sketch of the Changjiang Estuary (1 = Eastern Chongming Shoal; (2) = Eastern Hengsha Shoal; (3) = Jiuduan Shoal; (4) = Nanhui Shoal; $\mathrm{a}=\mathrm{CS} 1 ; \mathrm{b}=\mathrm{CS} 2 ; \mathrm{c}=\mathrm{CS} 2 ; \mathrm{d}=\mathrm{CS} 4 ; \mathrm{e}=\mathrm{H} 09 ; \mathrm{f}=\mathrm{H} 10 ; \mathrm{g}=\mathrm{H} 11 ; \mathrm{h}=\mathrm{H} 12 ; \mathrm{i}=\mathrm{H} 15)$. (b) Bathymetry in the North Passage and its adjacent regions. The solid lines represent the along-channel and crosschannel transects. (c) Bathymetry along the longitudinal transects. (d) Bathymetry along the transverse section.

\section{Study Site}

The Changjiang Estuary is a multichannel system, with three-level bifurcation and four outlets (i.e., North Branch, North Channel, North Passage, and South Passage, Figure 1a). The estuary segment is about $120 \mathrm{~km}$ long, measured from the headwater to the river mouth. The estuary has a funnel-shaped topography. The width of the estuary is approximately $90 \mathrm{~km}$ at the river mouth and decreases to $6 \mathrm{~km}$ at the apex. The estuary receives an annual mean freshwater discharge of $29,400 \mathrm{~m}^{3} / \mathrm{s}$ from the Changjiang River, with strong seasonal variations from 10,000 to $60,000 \mathrm{~m}^{3} / \mathrm{s}$. The Changjiang Estuary is characterized by a meso-tidal regime with a mean tidal range of $2.66 \mathrm{~m}$ and maximum tidal range of $4.62 \mathrm{~m}$ near the estuary mouth. The tidal range decreases in the landward direction within the estuary. Under the combined influence of a freshwater input and tide, the tidal currents in the estuary are strong with maximal current velocity up to $3.0 \mathrm{~m} / \mathrm{s}$. The estuary is a partially mixed estuary; however, it may change to a highly stratified or mixed estuary depending on tidal ranges and river discharge.

Massive amounts of sediment are carried to the estuary by the large river runoff. The annual sediment load was approximately $390 \times 10^{6}$ t. The riverine sediment acts as the main source for estuarine deposition. As a result, large sand bars and several islands (i.e., Chongming Island, Changxing Island, Hengsha 
Island, and Jiuduan Shoal, see Figure 1 for detail) are formed inside the estuary, and the estuary took shape of multiple channels. The shallow shoals would be submerged during high tide, inducing water exchange between the channels. The cross-shoal flow over Jiuduan Shoal (Figure 1b) generates a strong northward lateral flow with an amplitude up to $0.2 \mathrm{~m} / \mathrm{s}$, which is far greater than that in single-channel estuaries (Zhu et al., 2018). The turbidity maximum zone, formed under the combined influence of estuarine circulation (Liu et al., 2011), sediment flocculation (Guo et al., 2017), and tidal asymmetry (Li et al., 2015), is located in the North Channel, North Passage, and South Passage. Water depth is shoal in these channels with an averaged depth of $7 \mathrm{~m}$ due to sediment accumulation (Chen et al., 1999). To improve the navigable capacity, the North Passage was selected as the main navigation channel where two jetties and a series of groins were constructed during 1998-2010, called the Deep Waterway Project (DWP) (Figure 1a). The regulated navigation channel is approximately $50 \mathrm{~km}$ long, 350-400 $\mathrm{m}$ in width, and the main channel was deepened to $12.5 \mathrm{~m}$ at the cost of intensive dredging. Following completion of the DWP, the lateral water exchange between the channels was largely blocked (Jiang et al., 2012). Numerical experiments have revealed that the stratification was largely enhanced in the lower part of the channel (Wang et al., 2010). However, the change in three-dimensional hydrodynamics as well as their impact on stratification is poorly known.

\section{Methods}

\subsection{Numerical Modeling}

The EFDC (Environmental Fluid Dynamic Codes) developed by Hamrick (1996) was used in this study. This model has been successfully applied to many water bodies, such as estuaries, lakes, rivers, and lagoons (Jeong et al., 2010; Ji et al., 2001; Lin \& Kuo, 2003; Park et al., 2005). The model solves the Navier-Stokes equation for a domain under the free-surface assumption. The modified Mellor-Yamada level 2.5 turbulence closure is implemented in the model to obtain the vertical turbulent viscosity and diffusivity (Galperin et al., 1988; Mellor \& Yamada, 1982). The model uses curvilinear-orthogonal grids in the horizontal plane and sigma coordinates in the vertical direction. In this study, the model domain covers the entire East China Sea, Bohai Sea, and Yellow Sea, which has been used to study the morphological evolution of the Changjiang Estuary (Zhu et al., 2016). The use of a large domain model can reduce the errors induced by the influence of the tidal boundary condition, thus improving the tide simulation inside the estuary. The model has 25,922 grid cells with cell size varying from approximately $150 \mathrm{~m}$ inside the estuary to $30,000 \mathrm{~m}$ along the continental shelf. To represent the complex geometry in the branched estuarine system, the grids follow the deep channels, and highresolution grid cells are placed in the North Passage. Sixteen water column layers with the same thickness are specified in the vertical direction using sigma coordinates. The upstream riverine boundary was located at Datong station (tidal limit of the estuary), where daily freshwater discharge is measured. Nine harmonic tidal constituents, namely, $\mathrm{M}_{2}, \mathrm{~S}_{2}, \mathrm{~N}_{2}, \mathrm{~K}_{2}, \mathrm{O}_{1}, \mathrm{~K}_{1}, \mathrm{P}_{1}, \mathrm{M}_{4}$, and $\mathrm{MS}_{4}$, are forced at the open sea boundary. The tidal constituents are extracted from the global tidal data from the Delft Dashboard (http://delft-dashboard.software.informer.com). The salinity at the open boundary is set at 34 psu since the water near the continental shelf is primarily saline with little freshwater influence. A time step of 30 $\mathrm{s}$ is used in the model. The hydrodynamic roughness, which varies from 0.002 to $0.008 \mathrm{~m}$, is used in the model based on the model calibration. To better simulate the hydrodynamics in the shallow shoals, the wetting-drying method is switched on during the simulation. A no-slip condition was applied on the lateral and bottom boundaries. To simulate the temperature, we collected the atmospheric pressure, atmospheric temperature, solar shortwave radiation, relative humidity, evaporation, precipitation, and cloud cover to establish the temperature module (Hamrick, 1996). These data were obtained from the NCEP/NCAR Reanalysis. Because the surface-bottom temperature difference has minor effect on density inside the estuary, the density stratification is dominated by salinity for the area in this study.

The numerical simulations were conducted for scenarios based on the bathymetries in 1997 and 2010 to examine the alteration of hydrodynamics prior to and after the DWP construction. For the 2010 simulation, the training walls and groins were simulated by blocking specified grid cell faces, and with this information, we can actually reproduce the tidal current following the completion of DWP. The multiyear (1950-2010) averaged river discharge of $29,400 \mathrm{~m}^{3} / \mathrm{s}$ was used at the riverine boundary to represent the hydrodynamics under normal conditions. These configurations of numerical models enable us to 
distinguish the changes in estuarine dynamics caused by the DWP. The model was initially run for 120 days under normal discharge to reach an equilibrium state. The model results for day 120 were saved and used as the initial condition. For each model experiment, a 90-day model run was conducted with the same boundary condition. A transverse section and an along-channel transect were chosen to examine the detailed change in salinity and tidal flow (Figure 1b). The horizontal coordinate is defined as positive upstream and positive north. The transverse section was located in the core of the turbidity maximum (Pu et al., 2015). The main channel has been deepened for approximately $5.5 \mathrm{~m}$ due to intensive dredging (Figure 1c). The transverse section exhibits a "U" shaped profile, with main channel in the middle within distance from 2.5 to $5.3 \mathrm{~km}$ (Figure 1d). Two shallow shoals are located in the southern and northern part of the transverse section, with water depths less than $5 \mathrm{~m}$ (which is called southern shoal and northern shoal hereafter). The channel was transferred from a shallow and wide tidal inlet to a dynamically narrow inlet, with Kelvin number decreases from 1.44 to 0.57. In the Changjiang Estuary, tides provide the main energy for water mixing (Wu et al., 2010). The tidal cycle during spring tide is selected to explore the stratification/destratification processes for all of the following analysis since the hydrodynamics exhibit fully three-dimensional characteristics with strong lateral flow (Zhu et al., 2018).

To evaluate the variation in stratification, the buoyancy frequency was calculated:

$$
N^{2}=-\frac{g}{\rho_{0}} \frac{\partial \rho}{\partial z}
$$

where $N$ is the buoyancy frequency, $\rho_{0}$ is the reference density, $g$ denotes the gravitational constant and $\rho$ denotes the density in each water column layer. The influence of stratification on turbulent mixing can be examined by Richardson number (Ri):

$$
R i=\frac{N^{2}}{\left[(\partial u / \partial z)^{2}+(\partial v / \partial z)^{2}\right]}
$$

where $\partial u / \partial z$ and $\partial v / \partial z$ are the vertical shear in along-channel and lateral velocity. The critical value for active mixing is $R i=0.25$, since it is a necessary condition for the occurrence of shear instability (Geyer \& Smith, 1987).

\subsection{Model Validation}

The model was validated for its capacity for simulation of both tidal currents and salinity before and after the construction of the DWP. Field data of tidal current and salinity during the summer in 2000 and 2013 were used and can be representatives for the hydrodynamics prior to and after the channel deepening. Both measurements were conducted during the spring tide and lasted for 25-28 hr. The field observation in the summer of 2000 was conducted along the North Passage (Figure 1b). The measurements in the summer of 2013 were deployed in both North Passage and the adjacent area. These two sets of data enable us to examine the model performance for both local changes in hydrodynamics and large-scale three-dimensional currents and salinity over the Changjiang Estuary.

Comparison of tidal currents and salinity between model results and observations are shown in Figures 2 and 3, respectively. In general, the model results were consistent with observations in most observation sites. The tidal currents featured a rotating state off the estuary (Stations H10, H12, and H15 in Figure 2). When tides propagated into the estuary, the tidal currents became bidirectional and the currents speed increased significantly (Stations CS1-CS4 and H09 in Figure 2) due to the constricted geometry of the estuary. The model can precisely reproduce the tidal velocity and current direction against the field measurements in both 2000 and 2013. The modeled salinity varied almost the same range as the observed salinity during a flood-ebb cycle. Some discrepancies may be because of the complex bathymetry and the dynamics influenced by the partition ratios between the channels. Overall, the model performance is promising and can be used to simulate the hydrodynamics processes.

The model-data comparisons were further quantified by the correlation coefficient (CC) (Oke et al., 2002) 


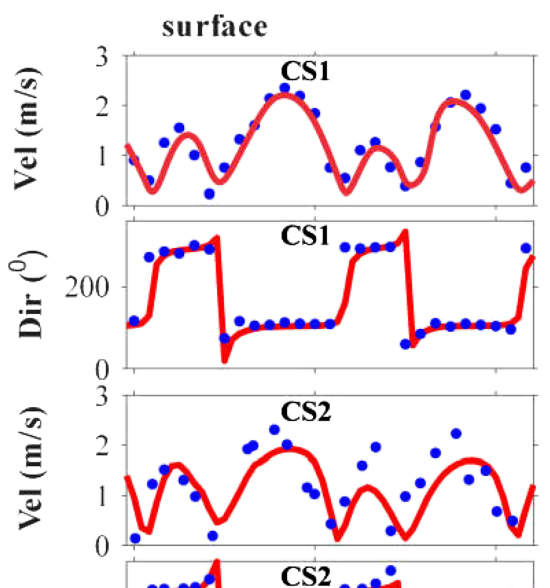

bottom
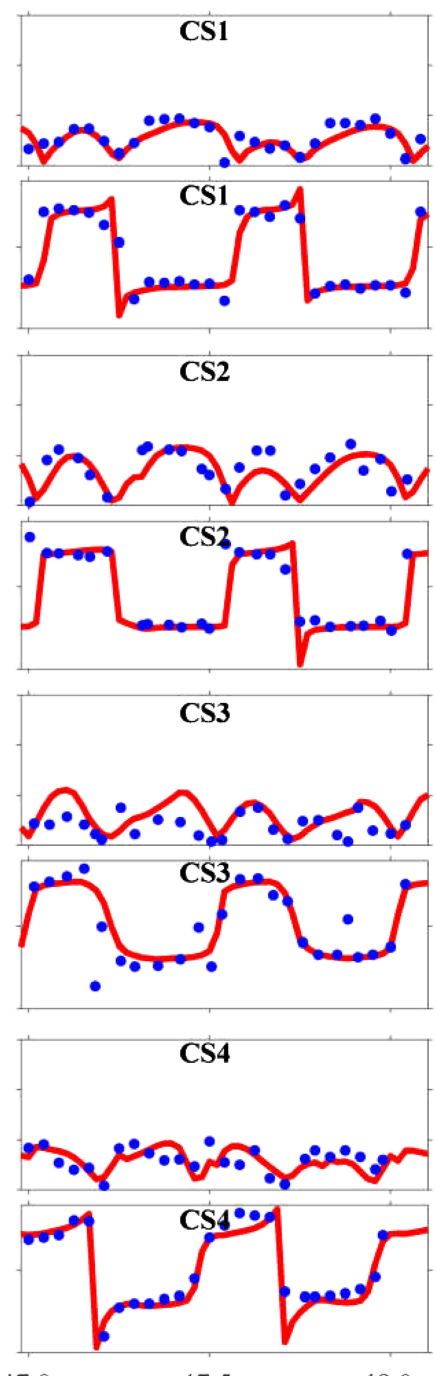

47.5

47.5

$48.0 \quad 47.0$

Days from 2000-07-01

Days from 2000-07-01

surface
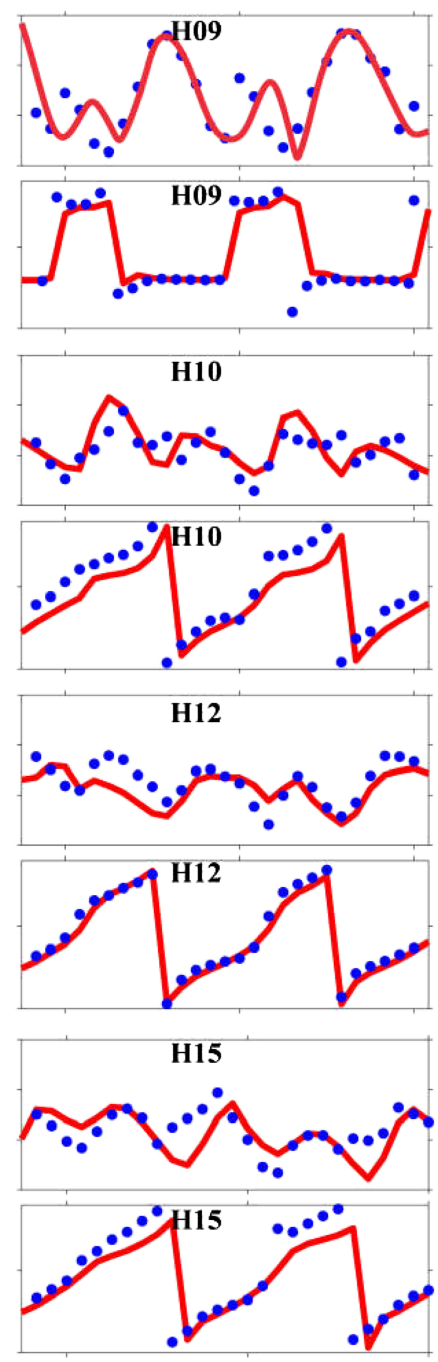

59.0

Days from 2013-06-01
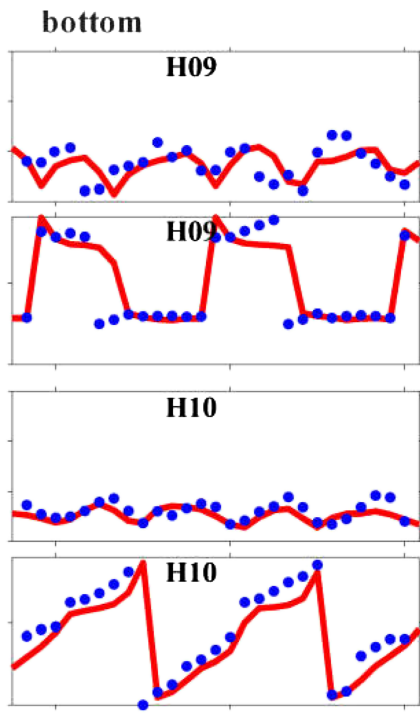

H12
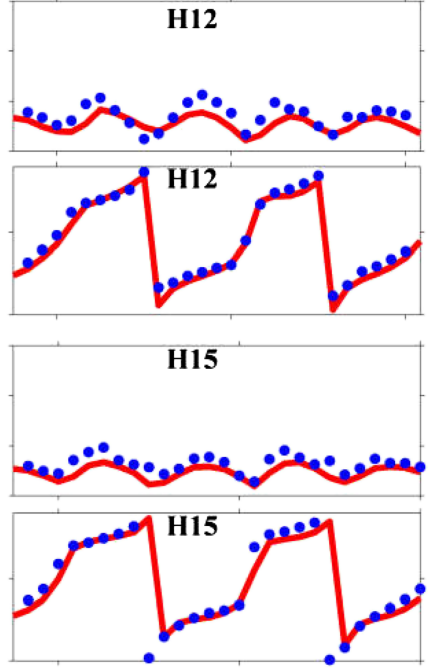

$59.5 \quad 58.5$

59.0

59.5

Days from 2013-06-01

Figure 2. Comparisons of the observed (dots) and modeled (solid line) tidal current.

$$
C C=\frac{1}{N} \sum_{i=1}^{N} \frac{(m-\bar{m})(o-\bar{o})}{S_{m} S_{o}}
$$

and the skill scores (SS) (Allen et al., 2007; Murphy, 1988)

$$
S S=1-\frac{\sum_{i=1}^{N}(m-o)^{2}}{\sum_{i=1}^{N}(o-\bar{o})^{2}}
$$

where $m$ and $o$ are the modeled and observed time series values, which have mean values $\bar{m}$ and $\bar{o}$ and standard deviations $S_{m}$ and $S_{o}$, respectively. The skill score shows an index of model-data agreement, with a skill value of 1 indicating perfect agreement and a value of 0 indicating complete disagreement.

The correlation coefficient of tidal current ranges from 0.53 to 0.96 , with a mean value of 0.81 , which is statistically significant at a $96 \%$ confidence level. For current simulation, the skill score ranges from 0.51 to 0.83 

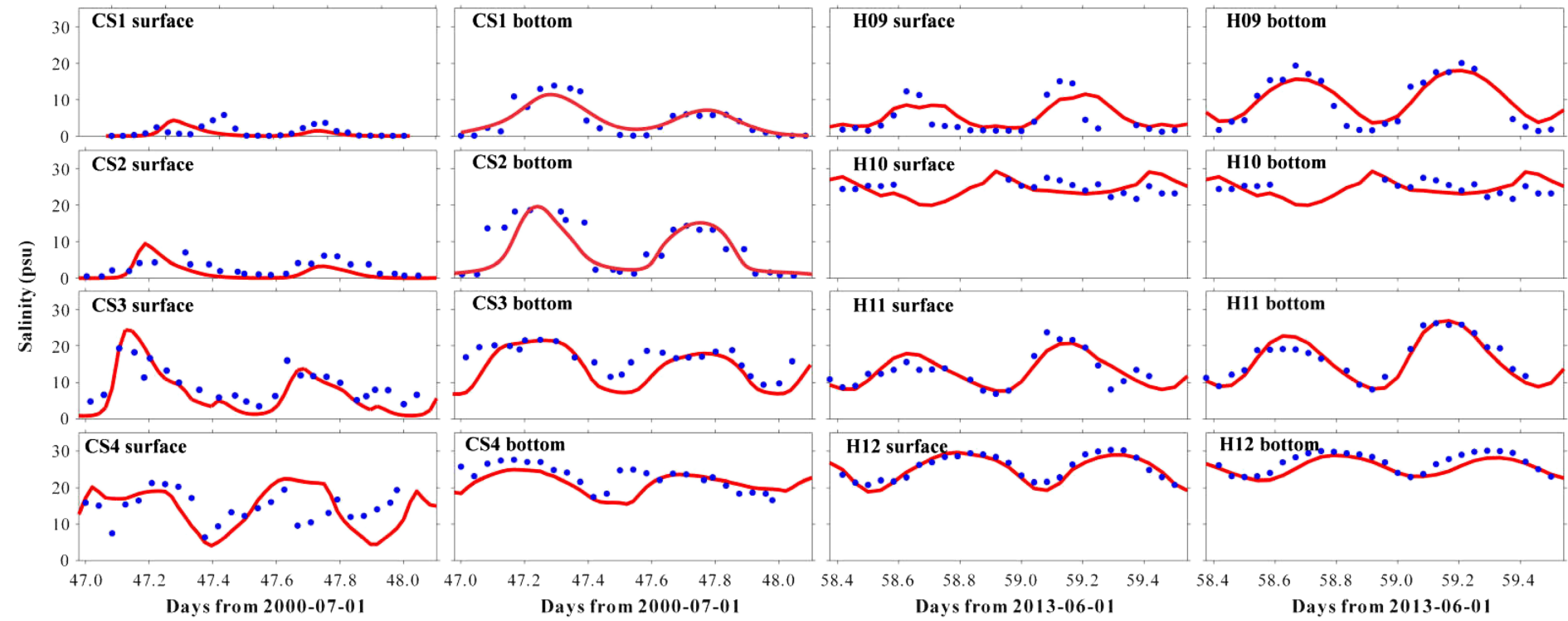

Figure 3. Comparisons of the observed (dots) and modeled (solid line) salinity.

and has a better performance near the bottom $(S S \approx 0.74)$ than near the surface $(S S \approx 0.68)$. The correlation coefficient of salinity varies from 0.58 to 0.98 with a mean value of 0.86 . The skill score of salinity simulation has a better skill near the surface $(S S \approx 0.85)$ than the near bottom $(S S \approx 0.73)$. Overall, the model results are reliable and the model can be used to diagnoses the change in hydrodynamics due to construction of the DWP.

\subsection{Evolution of the Vertical Salinity Gradient}

Many previous studies used potential energy anomaly dynamic equation to investigate the dominant factors controlling the stratification (Becherer et al., 2015; Burchard \& Hofmeister, 2008; Cheng et al., 2009). Li et al. (2018) also compared the influence of tidal training and mixing on stratification by using salinity variance method. They examined the major factors that controls the stratification processes for both the estuary mouth and the plume region in the Changiiang Estuary and found that the competition between tidal straining and mixing results in destratification during flood tide and restratification during ebb tide. However, they did not make the distinguish between the contributions from lateral and along-channel straining since they focus on the salinity variance controlled by the continuous freshwater input and periodic saltwater input from the ocean controlled by tides for a large-scale region. Here we apply a more direct approach to investigate the change in the vertical salinity gradient based on the salt transport equation:

$$
\frac{\partial s}{\partial t}=-u \frac{\partial s}{\partial x}-v \frac{\partial s}{\partial y}-w \frac{\partial s}{\partial z}+\frac{\partial}{\partial z}\left(K_{v} \frac{\partial s}{\partial z}\right)+\frac{\partial}{\partial x}\left(K_{h} \frac{\partial s}{\partial x}\right)+\frac{\partial}{\partial y}\left(K_{h} \frac{\partial s}{\partial y}\right)
$$

where $s$ denotes salinity; $t$ is time; and $u, v$, and $w$ are the velocity component along the $x, y$, and $z$ directions, respectively. $K_{v}$ and $K_{h}$ are the vertical and horizontal turbulent diffusivity, respectively. By taking the vertical derivative of the salt transport equation, we can obtain the evolution of the vertical salinity gradient (Scully \& Geyer, 2012):

$$
\begin{aligned}
& \frac{\partial \partial s}{\partial t \partial z}=-\frac{\partial u \partial s}{\partial z \partial x}-u \frac{\partial \partial s}{\partial x \partial z}-\frac{\partial v \partial s}{\partial z \partial y}-v \frac{\partial \partial s}{\partial y \partial z}-\frac{\partial w \partial s}{\partial z \partial z}-w \frac{\partial^{2} s}{\partial z^{2}}+\frac{\partial}{\partial z} K_{v}\left(\frac{\partial^{2} s}{\partial z^{2}}\right)+\frac{\partial}{\partial z} K_{h}\left(\frac{\partial^{2} s}{\partial x^{2}}+\frac{\partial^{2} s}{\partial y^{2}}\right)
\end{aligned}
$$

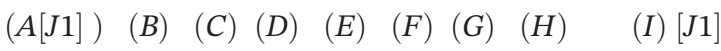

In equation (6), the term A denotes the evolution of the vertical salinity gradient. The terms on the right side are the main physical processes controlling the stratification. Terms B and D are the along-channel and lateral straining, respectively, which are induced by the interaction between the vertical shear of the tidal 
currents and the horizontal salinity gradient. Because of the horizontal gradients in $\partial s / \partial z$, the stratification can be modified by the along-channel (C) and lateral (E) advections. Similarly, the vertical velocity can also alter the stratification by expanding or compressing the vertical salinity gradient (F) or through vertical advection $(G)$ of the vertical gradient in $\partial s / \partial z$. The stratification can be diminished by vertical mixing $(H)$ and modified by horizontal mixing (I). The horizontal mixing terms, including both longitudinal and lateral mixing, are negligible in this study since they are several orders of magnitude smaller than the vertical mixing. By calculating each term in equation (6) at the selected transverse section, we can determine the dominant mechanism that controls the stratification before and after the DWP. To simplify the analysis, the crosssectionally averaged value of the terms in equation (6) was calculated.

\section{Results}

\subsection{Along-Channel Velocity and Salinity Structure}

The tidal current and salinity profile exhibited significant variation during a flood-ebb cycle. For the 1997 simulation, the depth-averaged tidal current is approximately $1.1 \mathrm{~m} / \mathrm{s}$ during the peak flood (Figure $4 \mathrm{a}$ ) and exhibits minor vertical shear except near the bottom (Figure 5a). Similar to the velocity profile, the salinity is nearly uniform in the vertical direction. Thus, the values of $N^{2}$ are less than $10^{-4} \mathrm{~s}^{-2}$ for most portion along the main channel (Figure 5e), suggesting that the density stratification is negligible. The current velocity decreases sharply during the flood slack (Figure $4 \mathrm{~b}$ ). At the region with distance between 17 and $40 \mathrm{~km}$, the directions of surface and bottom currents are opposite under the influence of a baroclinic force. A vigorous current shear is generated near the interface between landward and seaward flows (Figure $5 b$ ). In the salt front, where salinity is between 6 and $16 \mathrm{psu}$, the stratification is enhanced as shown by both the vertical salinity gradient and distribution of the squared buoyancy frequency (Figure 5f). During the peak ebb, the near surface tidal current exceeds $2.2 \mathrm{~m} / \mathrm{s}$ under the influence of freshwater (Figure 4c), and strong vertical velocity shear is exhibited in the upper water column (Figure $5 \mathrm{c}$ ). There is continuous stratification from the surface to bottom (Figure 5g). Then, the current speed decreases during ebb slack and the stratification is weakened as the salty water is pushed seaward (Figures $4 \mathrm{~d}$ and $5 \mathrm{~h}$ ).

For the 2010 simulation, both current velocity and vertical shear have increased in the upper water column during the peak flood (Figures $4 \mathrm{e}$ and $5 \mathrm{i}$ ). In the lower reach of the channel with distance $>30 \mathrm{~km}$, the bottom and surface current are out of phase and move in opposite directions during the flood slack (Figure 4f). The ebb currents are strengthened in the upper reach of the channel during the peak ebb (Figure 4g) as water masses concentrate in the main channel. During the ebb slack, a salt wedge develops, which is driven by a baroclinic-induced near-bottom landward flow (Figure 4h). The tidal currents during ebb tide show strong vertical shear in the upper water column and decrease by several orders of magnitude toward the sea bed (Figures $5 \mathrm{k}$ and 5l). The vertical distribution of current shear is mainly determined by the vertical transfer of momentum, for which we will discuss later. After channel narrowing and deepening, there is a persisting strong vertical salinity gradient in the upper water column (Figures $4 \mathrm{e}-4 \mathrm{~h}$ ). The bottom mixed layer is observed only during flood tide and constrained in the lower half of the water column. In accordance with the salinity structure, the squared buoyancy frequency has a value greater than $10^{-2} \mathrm{~s}^{-2}$ near the surface (Figures $5 \mathrm{~m}$ and $5 \mathrm{n}$ ). As the strong current shear strains the isopycnal continuously during ebb tide, density stratification is further developed and extends to the seabed (Figures 50 and $5 \mathrm{p}$ ).

\subsection{Transverse Structure of Tidal Current and Salinity}

To better investigate the changes in three-dimensional hydrodynamics, we analyzed both tidal current and salinity at the selected transverse section (the location is shown in Figure 1b). For the 1997 simulation, salinity is higher in the deep channel, and transverse salinity gradient is generated during the peak flood (Figures 6a and 6e). The baroclinic force, generated by the transverse salinity gradient, drives a southward lateral flow in the main channel with a magnitude less than $0.05 \mathrm{~m} / \mathrm{s}$. The magnitude of lateral flow exceeds $0.2 \mathrm{~m} / \mathrm{s}$ on the shoal, which is induced by the cross-shoal flow (Zhu et al., 2018). During flood slack, the lateral flow is greater in magnitude than the along-channel current and shows a two-layer structure flow with the surface flow directs to the north and near-bottom water flows southward. The strong lateral flow tilts isopycnal, setting up distinct salinity gradients in both the transverse and vertical directions (Figures $6 \mathrm{~b}$ and $6 \mathrm{f}$ ). The squared vertical shear in lateral flow has the same magnitude with the along-channel current shear during flood tide, with values ranging between $10^{-2}$ and $10^{-1} \mathrm{~s}^{-2}$ (Figures 7a, 7b, 7e, and 7f). During the peak 

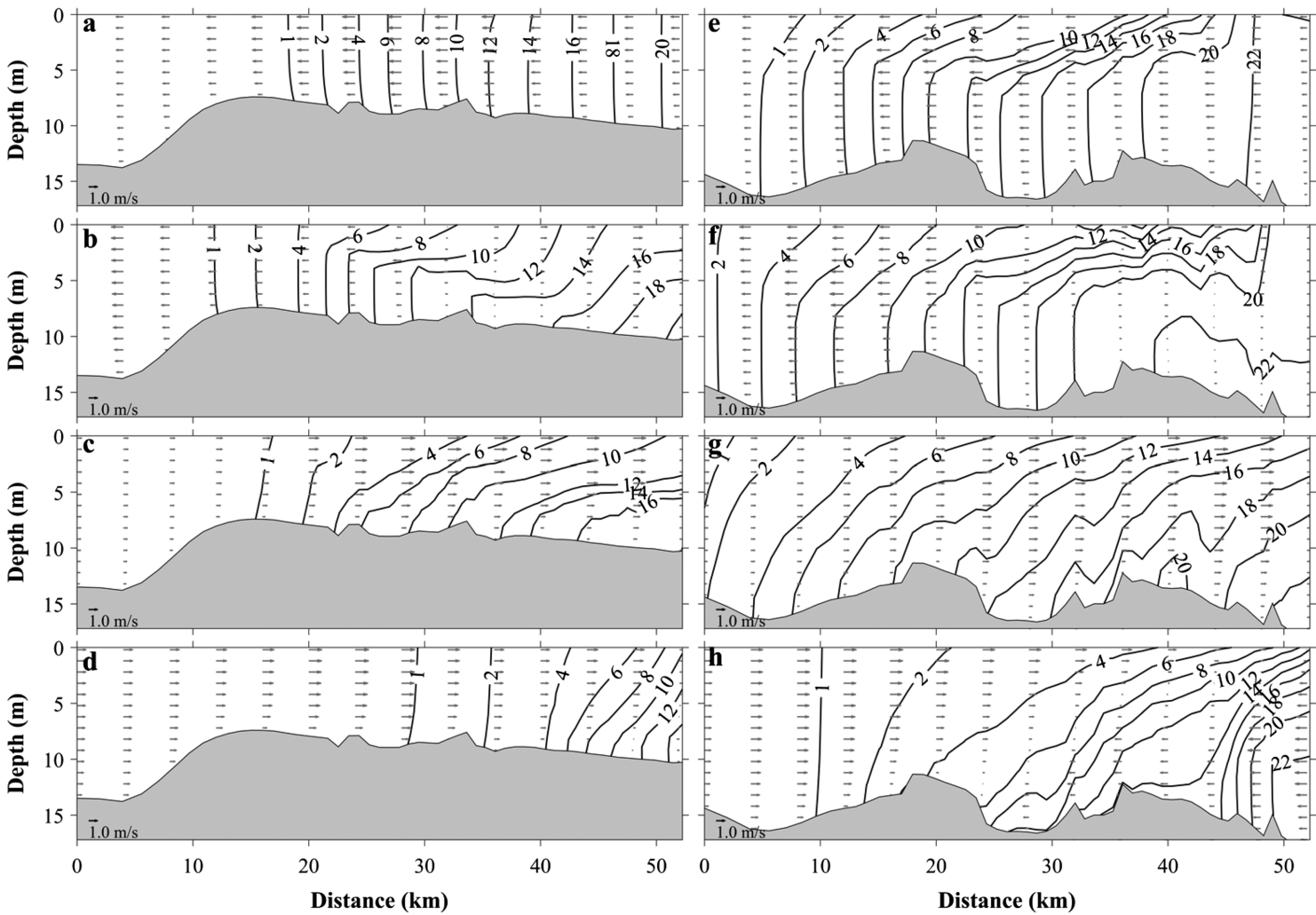

Figure 4. Salinity contours and along-channel velocity in the longitudinal transect (left column = 1997; right column = 2010. (a, e) Peak flood; (b, f) flood slack; (c, g) peak ebb; (d, h) ebb slack).

ebb, the vertical salinity gradient further increases in the main channel, while the southern shoal remains well-mixed due to bottom friction (Figure 6c). Under the impact of freshwater input, the maximum alongchannel current reaches $2.4 \mathrm{~m} / \mathrm{s}$ and there is pronounced vertical shear in the upper water column with water depth less than $5 \mathrm{~m}$ (Figures $6 \mathrm{~g}$ and $7 \mathrm{c}$ ). The vertical shears for both along-channel and lateral flow
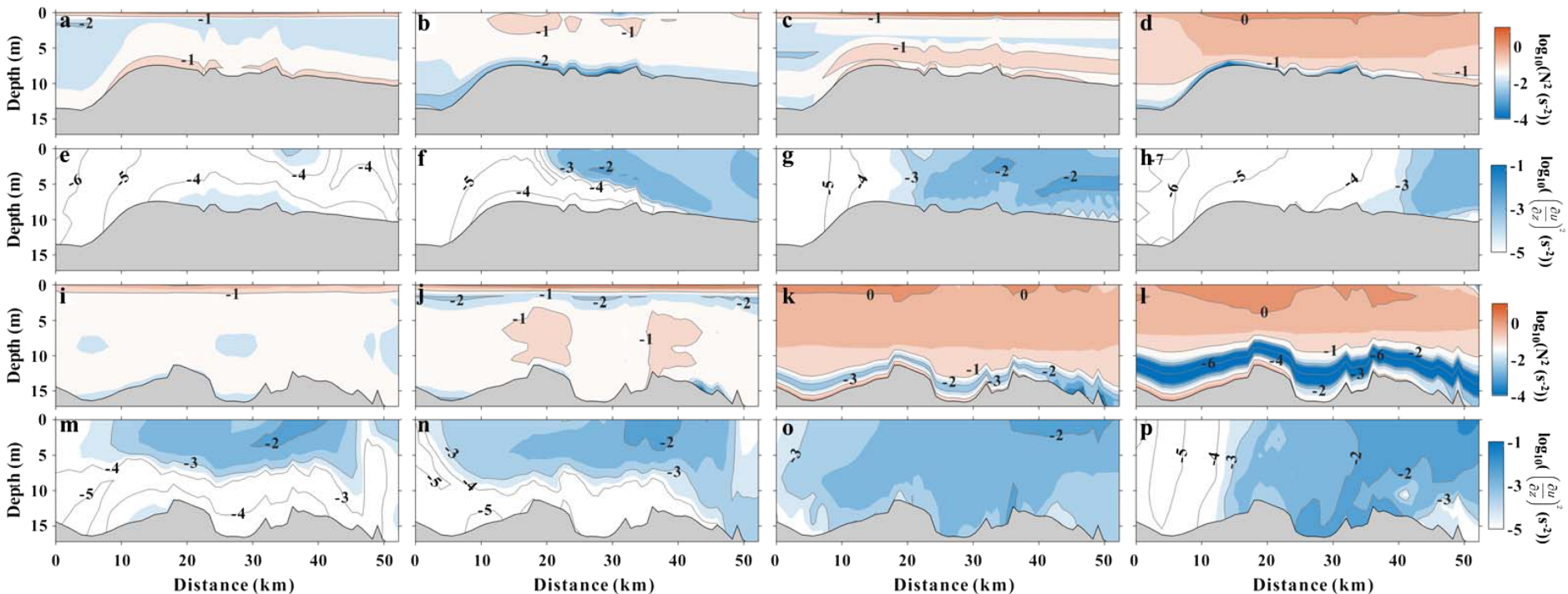

Figure 5. Longitudinal distributions of squared along-channel velocity shear ((a-d) 1997, (i-1) 2010, shown in log10 scale) and squared buoyancy frequency ((e-h) 1997, (m-p) 2010, shown in log10 scale), from left to right: peak flood, flood slack, peak ebb, ebb slack. 

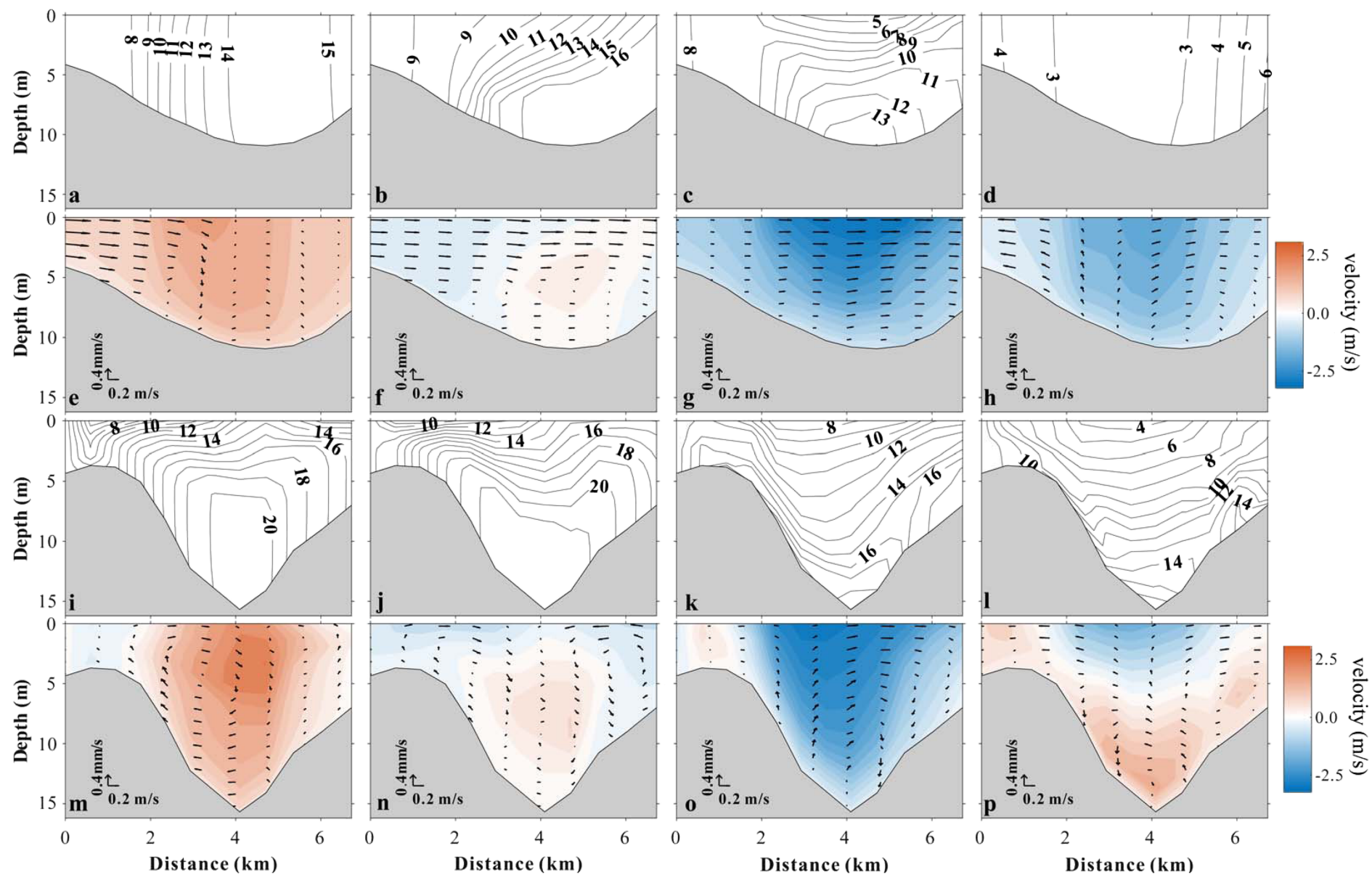

Figure 6. Distribution of salinity ((a-d) 1997, (i-1) 2010) and tidal currents (lateral flows are shown as arrows and contours denote along-channel velocity, (e-h) 1997, (m-p) 2010) at the transverse section, from left to right: peak flood, flood slack, peak ebb, ebb slack.

decrease by several orders of magnitude below the pycnocline (Figure 7g). During the ebb slack, the salty water located on the lateral slope (Figure 6d), which is caused by the rapid downstream movement of water parcel in the deep channel. The lateral flow is rapidly reduced and has a divergent structure (Figure 6h), which features the characteristics of lateral flows driven by differential advection (Lerczak \& Geyer, 2004; Nunes \& Simpson, 1985).

For the 2010 simulation, the vertical salinity gradient remains strong over the entire flood-ebb cycle (Figures 6i-61). Only during the flood tide, the water column below the pycnocline is well-mixed due to mixing near the bottom. The along-channel tidal currents on the shallow shoal are highly influenced by the newly built dikes and groins. Because of the sheltering effects of the groins, the along-channel velocity on the shoal is largely reduced (Figures $6 \mathrm{~m}-6 \mathrm{p}$ ). Thus, strong vertical salinity gradient is presented on the shallow shoal due to the infirm interaction between tidal currents and seabed. While in the main channel, the maximum along-channel velocity is present at the subsurface layer during the flood period, which is likely to be caused by redistribution of eddy viscosity in highly stratified waters (Chen \& De Swart, 2016). During ebb tide, the vertical salinity gradient further increases and bottom mixed layer is constrained close to the bed (Figures $6 \mathrm{k}$ and 61). The along-channel velocity in the main channel has a similar magnitude with that before channel narrowing and deepening during the peak ebb. The flow becomes weak during the ebb slack and the near-bottom current turns landward. The lateral flow during flood tide shows a convergent structure in the main channel and two other gyres generate on the shoals. It is noted that a stronger vertical velocity can be observed, which is induced by the isopycnal tilting near the lateral boundary (Garrett et al., 1993; Lerczak \& Geyer, 2004). However, the magnitude of transverse velocity is largely reduced from the late 

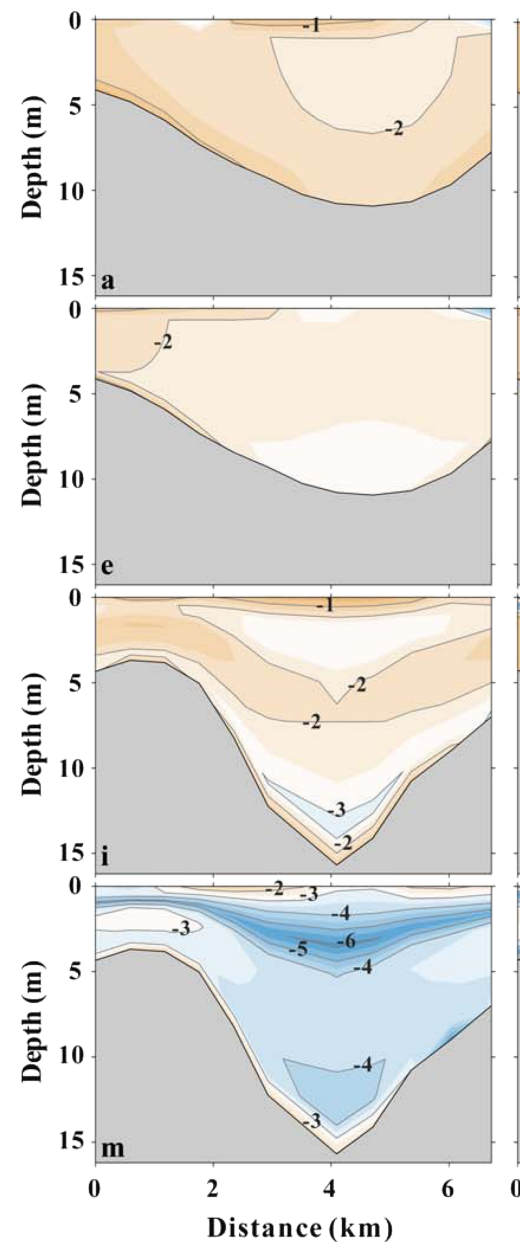
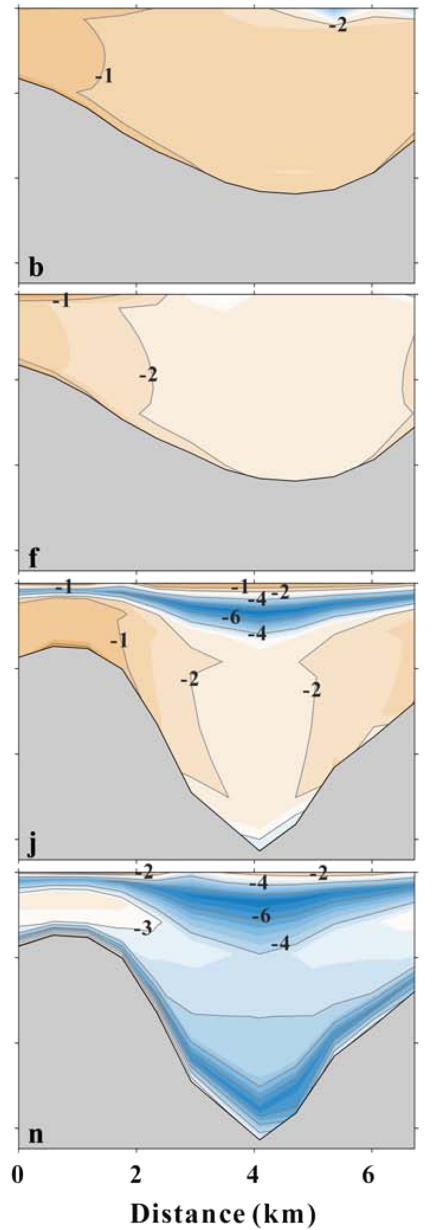
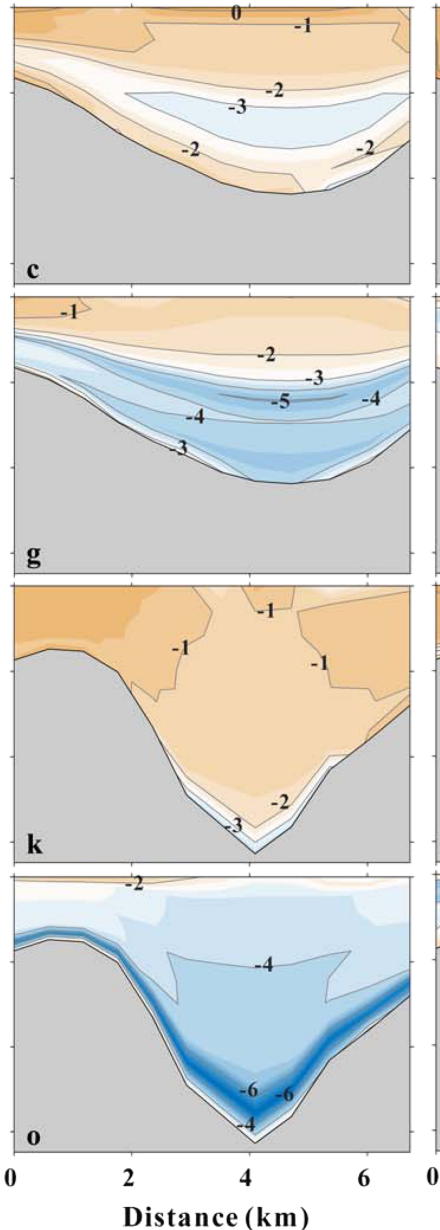

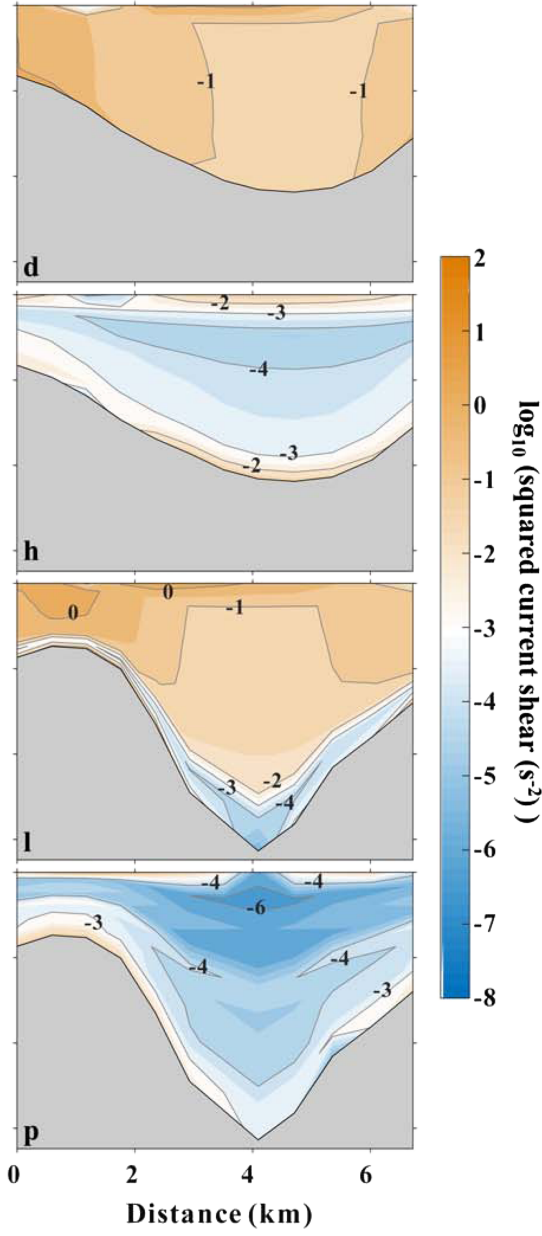

Figure 7. Transverse distributions of squared along-channel velocity shear ((a-d) 1997, (i-1) 2010, shown in log10 scale) and squared lateral current shear ((e-h) 1997, (m-p) 2010, shown in log10 scale), from left to right: peak flood, flood slack, peak ebb, ebb slack.

flood to the ebb tide. The lateral current is divergent near the surface and has two eddies rotating reversely compared to flood tide. The changes in bathymetry and density field further modified the vertical velocity profile. The vertical shear of along-channel velocity is in comparable magnitude during flood period with that for the 1997 simulation (Figures $7 \mathrm{i}$ and $7 \mathrm{j}$ ). During ebb tide, the along-channel velocity shear increases in the upper column with depth $<7 \mathrm{~m}$ (Figures $7 \mathrm{k}$ and $7 \mathrm{l}$ ). However, regions with minor vertical shear can be observed for both flood and ebb tide, which is mainly induced by the vertical momentum transfer (Souza \& Simpson, 1997). The vertical shear in lateral flow decreases for several orders of magnitude over the entire tide period because of significant reduction in lateral flows (Figures $7 \mathrm{~m}-7 \mathrm{p}$ ).

\subsection{Stratification}

To better evaluate the variation of stratification due to channel modification, we examined the value of $N^{2}$ at the transverse section. For the 1997 simulation, the values of $N^{2}$ range from $10^{-5}$ to $10^{-2} \mathrm{~s}^{-2}$ during an intratidal time period (Figures 8a-8d), which is consistent with the variation in salinity structure. The stratification is weak during the peak flood as shown by the squared buoyancy frequency, with values around $10^{-4}$ $\mathrm{s}^{-2}$. Later during the flood slack, the stratification is shown to be rapidly enhanced in the upper water column of the main channel. The stratification is further enhanced during the early ebb and maximum stratification occurs at peak ebb. On the contrary, the water column remains well-mixed on the shallow shoal and around the lateral boundary due to bottom friction. Then, stratification is broken down at the end of the ebb tide as salt water is transported downstream. 

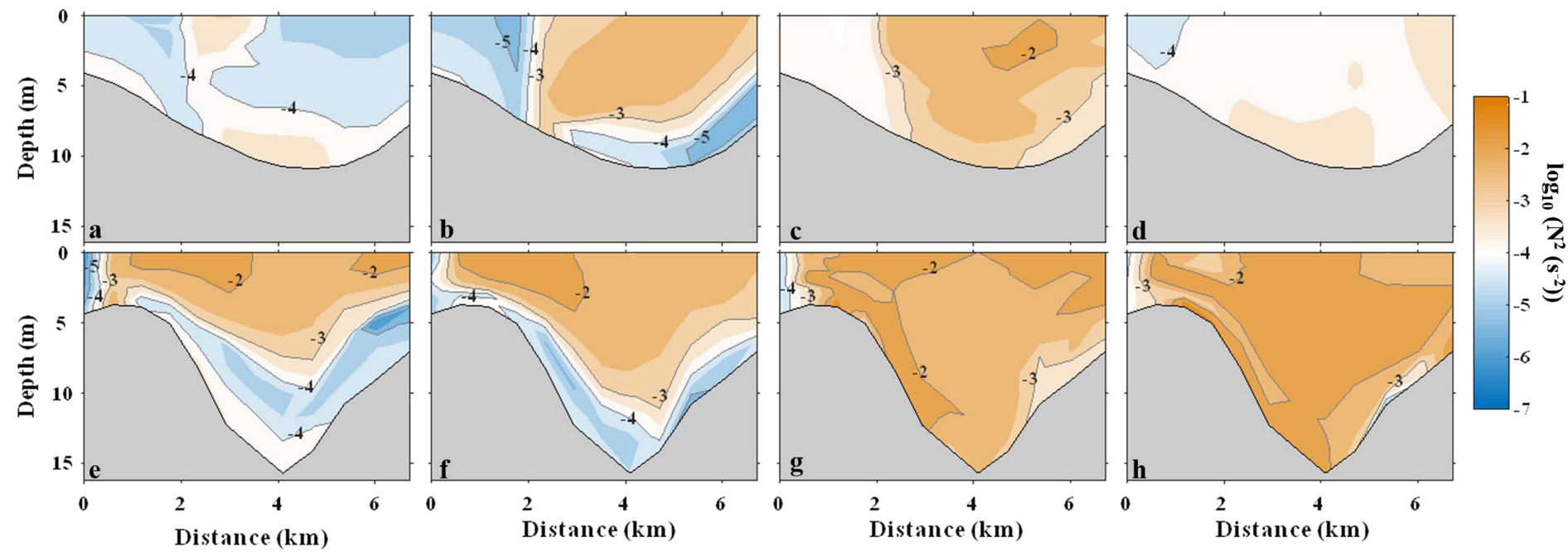

Figure 8. Transverse distributions of squared buoyancy frequency (shown in log10 scale, upper panels = 1997; lower panels = 2010. (a, e) Peak flood; (b, f) flood slack; (c, g) peak ebb; (d, h) ebb slack).

The density stratification is found to be enhanced and experiences less intratidal variation after channel narrowing and deepening (Figures 8e-8h). Large values of $N^{2}$, with magnitudes of $10^{-2} \mathrm{~s}^{-2}$, are observed in the upper water column. Spatially, the value of $N^{2}$ varies for two orders of magnitude in the vertical direction during flood tide. The stratification expands over most part of the transverse section during ebb tide and becomes most stratified at the end of the ebb tide. The intratidal variation in stratification suggests that the dominant mechanism affecting stratification may have changed, and we will discuss this in detail later.

\subsection{Evolution of Vertical Salinity Gradient}

Based on the salinity distribution and tidal flow structure, we will show how these variables interact and finally alter the stratification. For the 1997 simulation, the vertical shear in along-channel velocity strains the isopycnal, which destratifies the water column during flood tide and restratifies the water column during ebb tide (Figure 9a). Similar to the along-channel straining, the interaction between transverse salinity gradient and vertical shear in lateral flow can also modify the stratification by straining the isopycnal transversely (Becherer et al., 2015; Scully \& Geyer, 2012). The lateral straining contributes positively to the density stratification and is not in phase with the along-channel straining. From the late flood to early ebb, the value of lateral straining exceeds that of the along-channel straining and contributes substantially to stratification, given a strong shear in lateral flow (Figure 7f) and a high lateral salinity gradient (Figure 6b). Because of the horizontal gradient in $\partial s / \partial z$ (Figures $8 \mathrm{~b}$ and $5 f$ ), both along-channel and lateral advections have similar magnitudes as the straining terms during early ebb. However, these advections tend to cancel each other out as the stratified water from downstream is advected upstream (Figure 4b), and the well-mixed water on the southern shallow shoal is advected northward to the main channel (Figure 6b). Therefore, the vertical salinity gradient is positive from the late flood to the early ebb (Figure 9c), and the stratification is most vigorous during the early ebb. During the late ebb, the stratification is broken down due to vertical mixing (Figure 9b) and advection of the less stratified water from upstream (Figures 4c), even the along-channel flow continues to strain the isopycnal.

The evolution of vertical salinity gradient is also performed for the 2010 simulation to analyze the mechanism controlling the stratification. The contribution from lateral straining on vertical salinity gradient is largely reduced as a result of decrease in both transverse salinity gradient and lateral flow shear (Figure 9d). The impact of lateral advection on stratification is also negligible since the lateral gradient in $\partial s / \partial z$ is largely reduced compared that in the 1997 simulation. Meanwhile, the along-channel staining is positive during most of a tidal cycle since a sharp front develops. This is consistent with the study of Li et al. (2018), in which they found the tidal straining is persistently positive inside the salt front regardless the tidal phase. The 

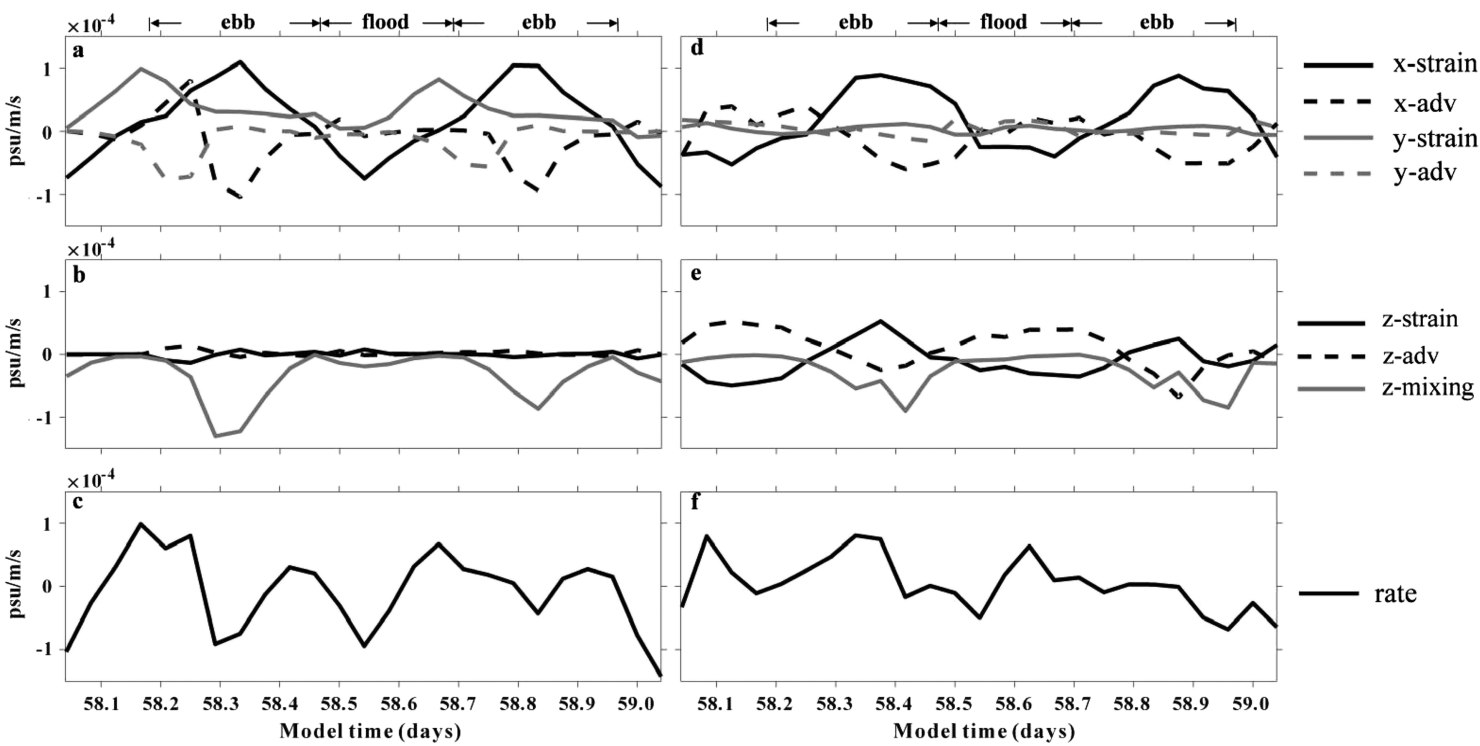

Figure 9. The time-series of cross-sectionally averaged values of the terms in equation (6). (left column = 1997; right column = 2010; (a, d) horizontal straining and advection; (b, e) vertical straining, advection and mixing; (c, f) evolution of vertical salinity gradient. $\mathrm{x}, \mathrm{y}$, and $\mathrm{z}$ demote along-channel, transverse, and vertical direction, respectively. "strain" and "adv" are abbreviations for straining and advection, respectively).

strong vertical shear in along-channel velocity strains the isopycnal consistently during the ebb tide, which lead to a continuous increase in the vertical salinity gradient. Thus, the water column becomes most stratified in the late ebb. Notably, the vertical straining and advection become apparent (Figure 9e). During the flood tide, the up-slope flow compresses the isopycnal and stratifies the water in the upper layer. On the other hand, the vertical advection drives less stratified flow upward, which has the opposite effect to vertical straining.

\section{Discussion}

\subsection{Impact of Large-Scale Circulation}

The water movement in the Changjiang Estuary is influenced not only by the tidal currents but also by freshwater dispersion and density-driven force, which cause complicated distribution of residual velocity and salinity. To examine the impact of net water movement on salinity distribution, we calculated the unit width residual flux (Wu et al., 2010):

$$
\vec{T} r=\frac{1}{n T} \int_{0}^{n T} \int_{-1}^{0} \vec{V}(H+\eta) d \sigma d t
$$

where $\vec{T} r$ is the unit width residual flux, $T$ is the period of the tidal cycle, $\vec{V}$ is the velocity vector, $\sigma$ is the relative depth ( 0 at the surface and -1 at the bottom), $t$ is the time, $n$ is a selected integer, $H$ and $\eta$ are water depth and surface elevation, respectively. We averaged the model output over two tidal cycles, about $25 \mathrm{hr}$ during the spring tide. The residual transport is mainly seaward in the South Branch due to river discharge (Figure 10a). The residual transport turns landward as results of density gradient and Stokes drift in the region of saltwater intrusion. A large portion of the residual transport passes through the shoal and causes water exchange between the main channels (i.e., South Passage, North Passage, and North Channel), which has been proved to be an important mechanism for salt water intrusion. The lateral water exchange is likely to induce lateral flow and transverse salinity gradient, which finally alters the stratification process by generating lateral straining (Zhu et al., 2018). The water in the offshore region of the two southern outlets (North Passage and South Passage) is diluted by the freshwater transported out of the North Channel. This would lead to a reduction in salt intrusion and the associated density gradient. The impact of the DWP on hydrodynamics is not only constrained in the North Passage. In the first place, the lateral water exchange is largely reduced (Figure 10b). The salt water intrudes into the river mouth mostly along the longitudinal direction. Therefore, the along-channel processes, including along-channel straining and advection, would 


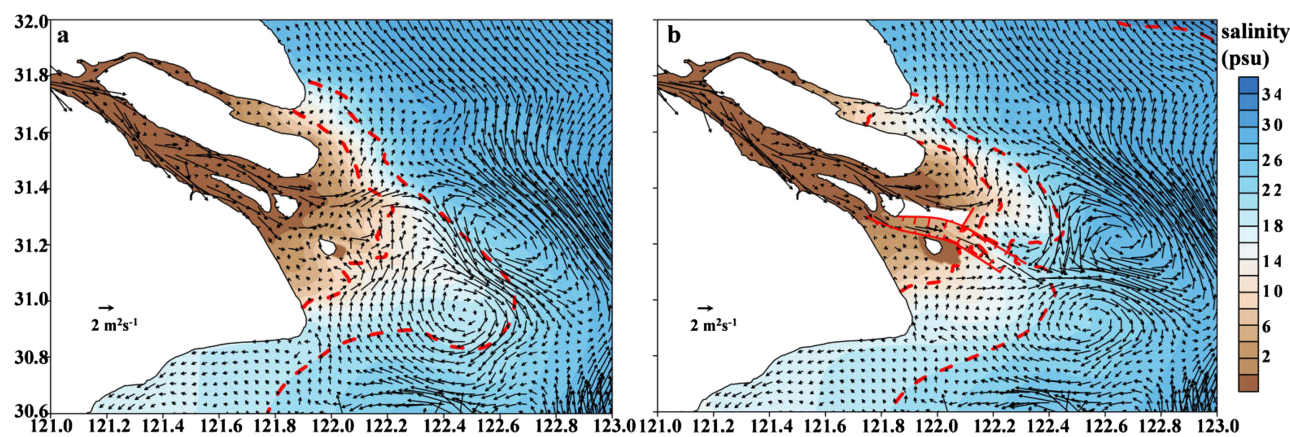

Figure 10. Unit width residual flux and surface salinity (contours for 10 and 20 psu are shown by thick red lines) in the Changjiang Estuary ((a) 1997, (b) 2010).

have major influence on the stratification. In addition, a mass of salt water is trapped near the mouth of the North Passage by the newly generated large eddy along the northern side of the training wall. The maintenance of salt water in the lower reach of the channel is highly possible to enhance stratification by interacting with the strong ebb currents.

\subsection{Turbulence Suppression}

We have shown that the stratification has been enhanced in the North Passage due to channel narrowing and deepening. Many studies have documented that the enhancement of stratification may suppress turbulent mixing (Geyer, 1993; Peters \& Bokhorst, 2000; Stacey \& Ralston, 2005). In this section, we will discuss to what extent the turbulent mixing is suppressed by the enhanced stratification by examining the Ri and turbulent viscosity. The turbulence suppression by stratification features an intratidal variation before channel deepening. The value of Ri is less than 0.25 over the entire transverse section during the peak flood (Figure 11a). In response, the water column experiences active turbulent mixing, with eddy viscosity reaching an amplitude of $10^{-2} \mathrm{~m}^{2} / \mathrm{s}$ in most part of the cross section (Figure 11e). During the flood slack, the Ri exceeds critical value of 0.25 only at a small part above the main channel (Figure 11b). Because the upward transfer of turbulence is reduced within the pycnocline, the turbulence is found to be suppressed in the upper $5 \mathrm{~m}$ above the main channel (Figure 11f). The area for turbulence suppression further expands during peak ebb as a result of stratification enhancement (Figure 11c). Active mixing is constrained close to the seabed in the main channel (Figure 11g). Because of the friction effects, the turbulent mixing is persistently vigorous on the southern shoal. As stratification is diminished during the ebb slack, the level of turbulence recovers with eddy viscosity ranging between $10^{-3}$ and $10^{-2} \mathrm{~m}^{2} / \mathrm{s}$ (Figures $11 \mathrm{~d}$ and $11 \mathrm{~h}$ ).

The value of Ri is persistently greater than 0.25 in the upper water column after channel narrowing and deepening (Figures 11i-111), suggesting that turbulence is permanently suppressed by stratification. During flood tide, the values of Ri decrease gradually toward the seabed as the friction effects become apparent. In accordance with the values of Ri, eddy viscosity decreases from $10^{-2} \mathrm{~m}^{2} / \mathrm{s}$ near the bottom to $10^{-5} \mathrm{~m}^{2} / \mathrm{s}$ at the surface, indicating turbulent mixing is constrained underneath (Figures $11 \mathrm{~m}$ and $11 \mathrm{n}$ ). During the ebb tide, density stratification is further augmented and sharp vertical salinity gradient is observed even close to the sea bed (Figures $6 \mathrm{k}$ and 61 ). In response, turbulence is found to be suppressed even close to the sea bed where local production of turbulence is expected (Monismith, 2010). Turbulent mixing is restricted in a thin layer in the main channel (Figures 11o and 11p) and can be reduced for several orders of magnitude within a distance less than $2 \mathrm{~m}$ from the bed. As a result of turbulence suppression, the stirring from vertical mixing becomes weak (Figure 9f) and the water column becomes stable with less intratidal variation in stratification.

In estuaries and coasts, the vertical structure of tidal current is determined by how the momentum from external forces (e.g., barotropic or baroclinic force) is vertically redistributed by friction (Souza \& Simpson, 1996; Visser et al., 1994). In this study, the vertical velocity profile is found to be altered because of turbulence suppression. For 1997 simulation, turbulence produced near the bed can be transferred to the surface during the peak flood. The vertical shear in along-channel velocity is nearly uniform when it receives the signal of both friction and external force (Soulsby, 1983). During the peak ebb, turbulent mixing is constrained below the pycnocline and the vertical transfer of momentum is largely reduced inside the 

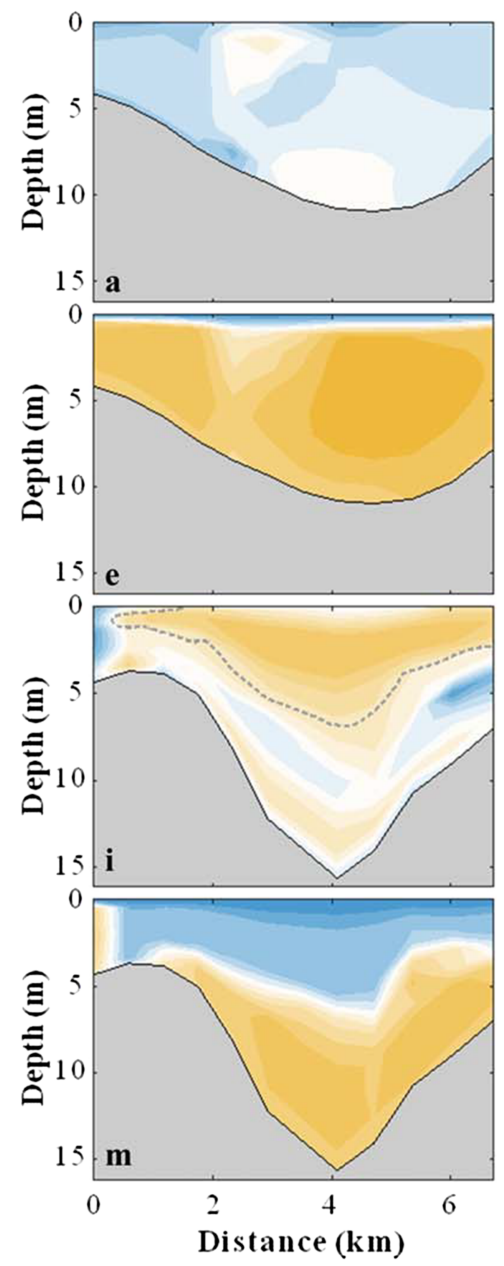
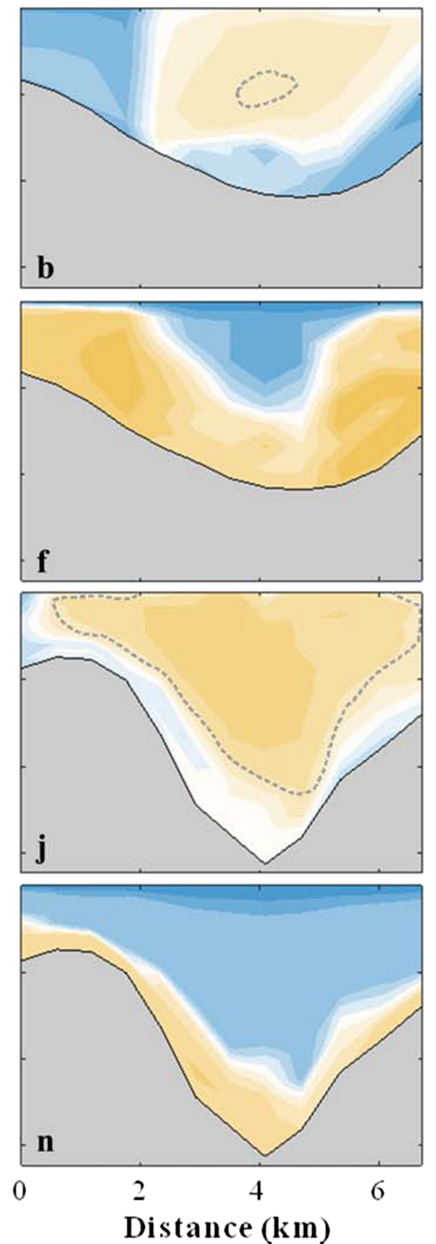
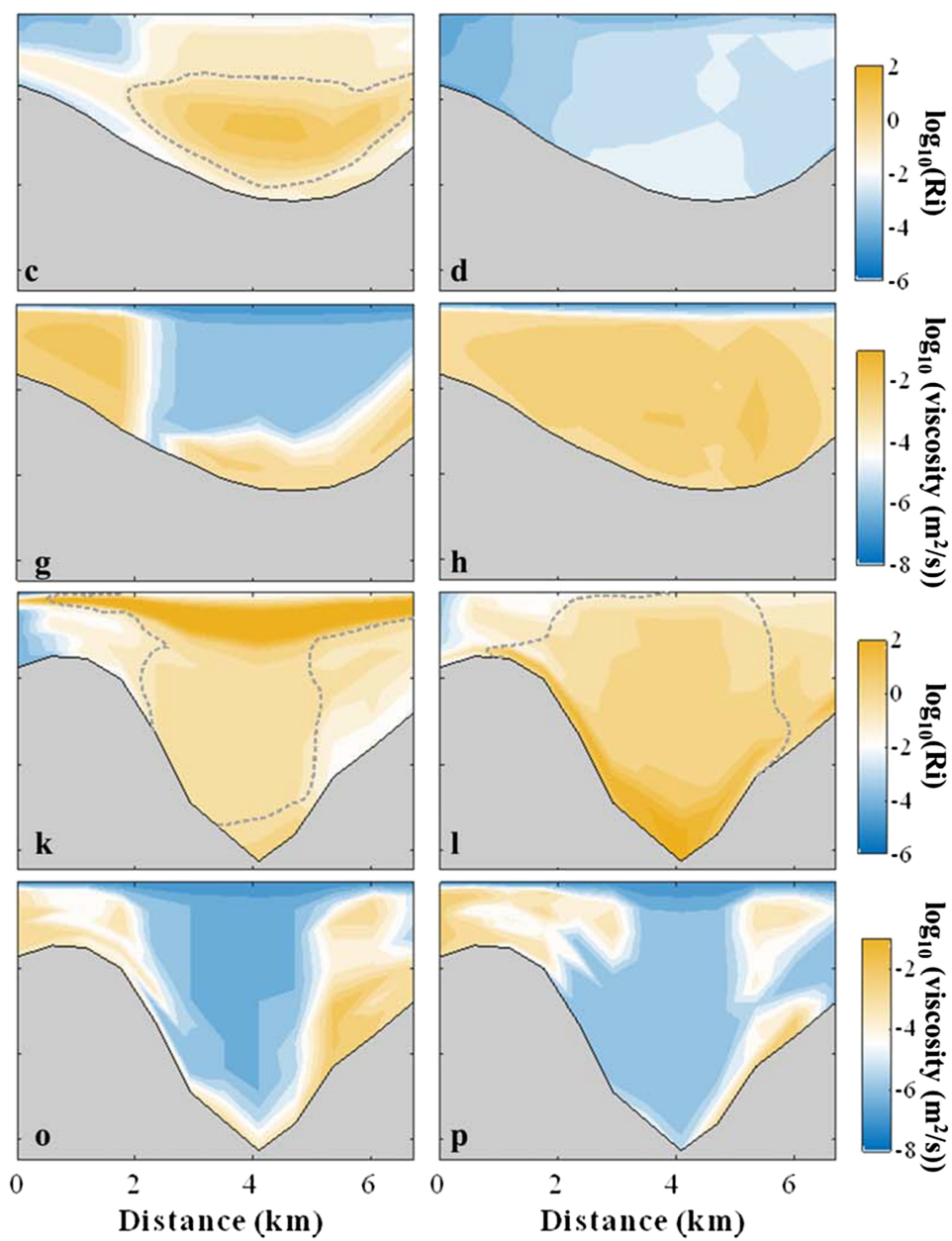
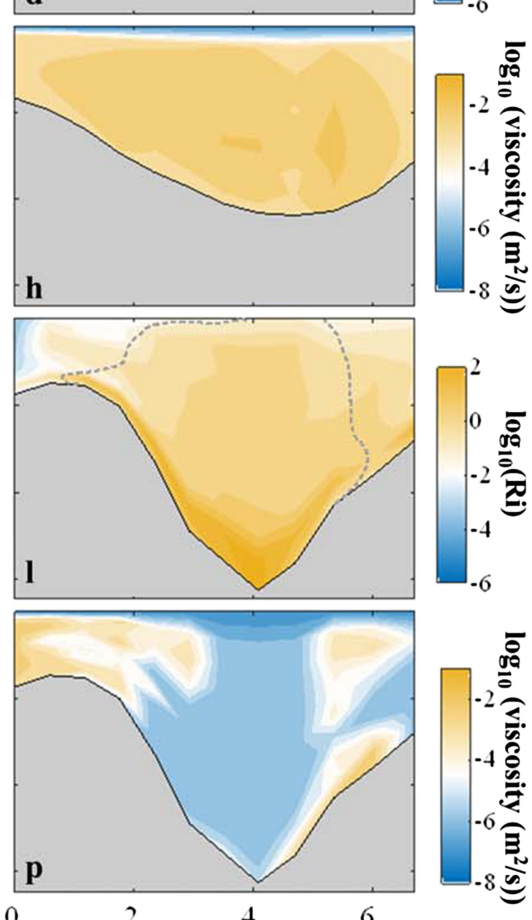

Figure 11. Transverse distributions of Richardson number ((a-d) 1997, (i-1) 2010, shown in log10 scale, dashed lines indicate the critical value) and eddy viscosity ((e-h) 1997, (m-p) 2010, shown in log10 scale), from left to right: peak flood, flood slack, peak ebb, ebb slack.

pycnocline as a result of stratification enhancement (Souza \& Simpson, 1997). Thus, along-channel vertical shear is reduced below the pycnocline due to excessive mixing (Chen \& De Swart, 2016). The water mass above the pycnocline is in free-stream, and a strong current shear is presented (Figure 7c). The bottom friction felt by the water is further reduced when stratification is enhanced after channel narrowing and deepening. The along-channel current shear experiences apparent reduction below the pycnocline. In the upper water column, the along-channel velocity magnitude is generally greater and shows a stronger shear, because of a decrease in vertical momentum exchange. By interacting with the along-channel salinity gradient, the current shear in turn strains the isopycnal and results in stratification enhancement.

\subsection{Generation of the Lateral Salinity Gradient}

Lateral salinity gradient has been shown to play an important role in stratification processes. To determine the main factor that produces the lateral salinity gradient, we adopt the approach of Chen and Sanford (2009) by laterally differentiating the salt transport equation:

$$
\frac{\partial}{\partial t} \frac{\partial s}{\partial y}=-\frac{\partial}{\partial y} \frac{\partial u s}{\partial x}-\frac{\partial}{\partial y} \frac{\partial v s}{\partial y}-\frac{\partial}{\partial y} \frac{\partial w s}{\partial s}+\frac{\partial}{\partial y}\left(K_{v} \frac{\partial^{2} s}{\partial z^{2}}\right)+\frac{\partial}{\partial y}\left(K_{h} \frac{\partial^{2} s}{\partial x^{2}}\right)+\frac{\partial}{\partial y}\left(K_{h} \frac{\partial^{2} s}{\partial y^{2}}\right)
$$

The term on the left side is the rate of change in the lateral salinity gradient, the first term on the right side is differential advection, the second and third term on the right are the advections by lateral motions, the fourth term is evolution in lateral gradient induced by vertical diffusion (hereafter called differential 
diffusion following Cheng et al., 2009), the last two terms are longitudinal and lateral turbulent diffusion. The horizontal diffusion terms are neglected in this study since they are generally several orders of magnitude smaller than the vertical diffusion (Li et al., 2014). To simplify the analysis, we calculate the crosssectionally averaged value of the terms in equation (8).

The differential advection is positive during the flood tide and negative during the ebb tide (Figure 12a). The lateral advection has the same magnitude as the differential advection, but they are nearly opposite in phase. The difference indicates that the lateral salinity gradient is mainly generated during the flood tide by differential advection (Lerczak \& Geyer, 2004; Nunes \& Simpson, 1985). As the lateral flow develops, it tilts the isopycnal and reduces the lateral density gradient. The differential diffusion is apparent during the ebb tide and generally produced by vertical turbulent diffusion. It sets an adverse pressure gradient to prevent the down-slope current from growing indefinitely. After channel deepening and narrowing, the flow is efficiently concentrated in the main channel and the differential advection plays a minor role in driving the lateral density gradient (Figure 12b). The differential diffusion becomes the main driver for lateral salinity gradient, which has also been proved in other stratified flows (Cheng et al., 2009; Li et al., 2014). However, the turbulent mixing is largely suppressed and active mixing is constrained near the sea bed. Thus, the transverse salinity gradient generated by differential diffusion is apparent only over the lateral boundaries (Figures $6 \mathrm{i}$ and $6 \mathrm{j}$ ).

\subsection{Contrast of Stratification Processes Between Spring and Neap Tides}

The results in this paper indicate that stratification/destratification is affected by the three-dimensional tidal and the large-scale density-driven currents before the construction of the DWP (Figures 9a-9c). After channel deepening, the stratification is more likely to be a two-dimensional process (Figures 9d-9f), which is dominated by along-channel tidal straining and vertical mixing even the analyses in this study are based on results during spring tides. Previous studies have demonstrated that the interaction between tide and shallow water depth is the major factor that causes mixing in the Changjiang Estuary (Wu et al., 2010; Zhu et al., 2016). The stratification is more vigorous during the neap tide than during the spring tide because less energy is available for vertical mixing ( $\mathrm{Pu}$ et al., 2015). In order to better understand the response of stratification to tidal current and its associated mixing, we examined the change in along-channel straining, lateral straining, and vertical mixing during neap tides according to equation (6).

Owing to the decrease in tidal currents and mixing, the straining terms and mixing are generally smaller during the neap tide than those during the spring tide (Figure 13), indicating the stratification features less variation during a flood-ebb cycle. Before channel narrowing and deepening, the lateral straining tends to persistently enhance the stratification and have an amplitude which is greater than the along-channel straining during the late flood. During the ebb, the along-channel straining is rapidly developed and controls the stratification process. The changes in the straining terms suggest lateral straining has the same effects during the neap tide, but it is not as significant as that during the spring tide. After channel narrowing and deepening, the contributions on stratification from lateral straining and vertical mixing becomes negligible in response to the enhancement in stratification (Jiang et al., 2012). Maximum stratification is expected to occur during the late ebb because along-channel straining becomes the dominant process.

Both the results for neap and spring tides indicate that the impact of lateral straining on stratification is proportional to mixing state in the estuary, because differential advection, the main driving mechanism for lateral flows, favors to develop in weakly stratified circumstance (Lerczak \& Geyer, 2004). The hydrodynamics in the Changjiang Estuary are also influenced by the seasonal variation in freshwater runoff. The estuary becomes stratified in wet season when there is massive buoyancy input and destratified in dry season given a decrease in river discharge (Wang et al., 2010). However, the length of saltwater intrusion, sediment load, and the large-scale density driven currents, which are also important in altering the stratification, vary accordingly to the river discharge. Therefore, more work is required to examine the how the results apply at seasonal timescales.

\subsection{Implications on Health of the Estuarine Ecosystem}

Many estuaries around the world have been deepened because of dredging for navigation and reclamation. These estuaries usually experienced enhancement of stratification as a result of redistribution of salinity and suspended sediment (De Jonge et al., 2014; Zaikowski et al., 2008). The enhanced stratification had a great 

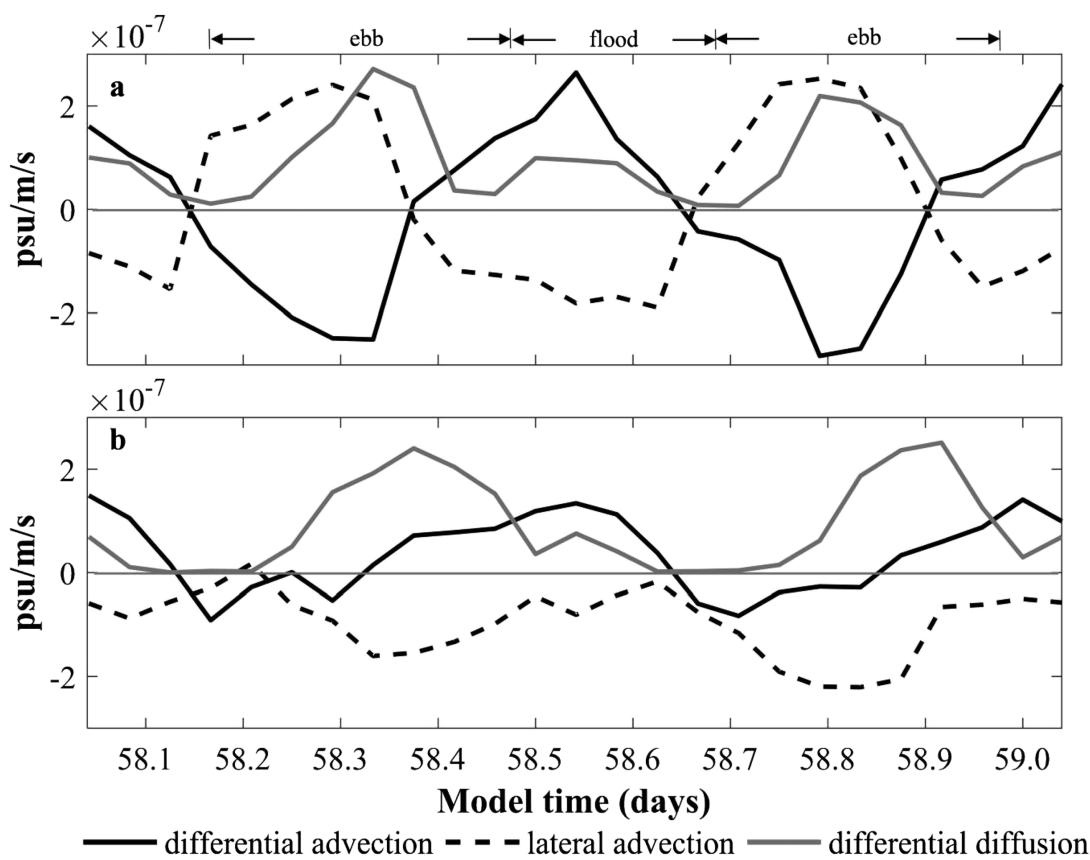

Figure 12. The time-series of the cross-sectionally averaged value of major terms in equation (8) ((a) 1997; (b) 2010).

impact on material transport and finally altered the sedimentary processes and estuarine ecosystem. For example, the Ems River has transited from a "normal" turbid system into hyper-concentrated one because of efficient trapping of fine sediment after a continuous deepening (Winterwerp, 2011). The deepening of the Ems Estuary also caused a reduction of dissolved oxygen over the past several decades and greater occurrence of hypoxic events, which pose threats on the ecosystem (Talke et al., 2009).

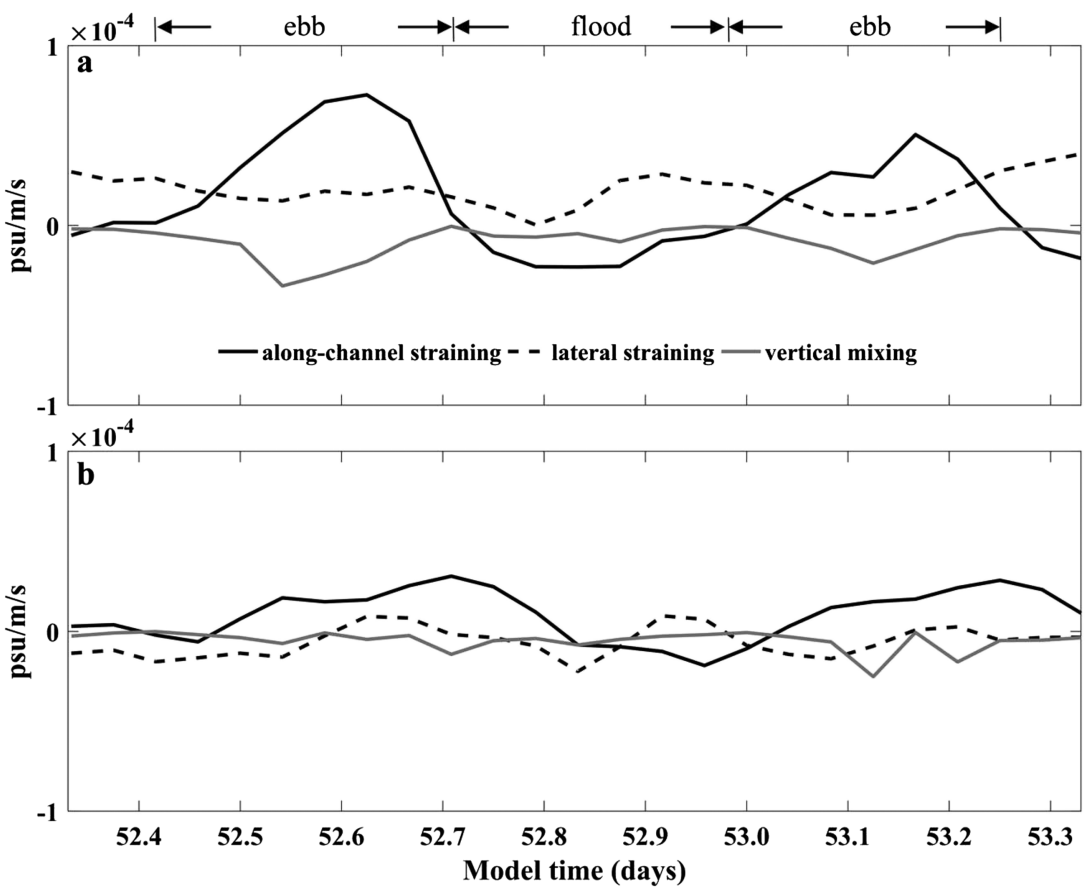

Figure 13. The time-series of cross-sectionally averaged values of along-channel straining, lateral straining, and vertical mixing during a neap tide ((a) 1997; (b) 2010). 
The Changiiang Estuary is inherently a highly turbid estuary. The sediments are major carrier for organic carbon and heavy metals because $92.5 \%$ of the suspended sediments have a grain size less than $62.5 \mu \mathrm{m}$ and are aggregated in transport (Liu et al., 2010). Thus, the transport of heavy metals is highly dependent on the sediment transport and exchange processes (Che et al., 2003). The deepening and narrowing of the North Passage has led to an increase in transport time and augmentation of estuarine circulation (Wang et al., 2010). The sediments cannot be suspended to the upper water column and high suspended sediment was restrained near the bed as a result of turbulence suppression. The trapping of sediment is quite possible to induce heavy metal accumulation, given sediment-water partition coefficients of greater than $30 \mathrm{~L} / \mathrm{g}$ for $\mathrm{Co}, \mathrm{Pb}$, and $\mathrm{Ni}$ (Feng et al., 2017). The resuspension of sediment in the turbidity maximum of the Changjiang Estuary has become the main source for heavy metals (Yin et al., 2016). The suspended sediment also reduced transparency of the water column, which further impacted phytoplankton photosynthesis and primary productivity in the estuary.

\section{Conclusion}

In this study, we conducted an analysis of stratification alterations in the North Passage of the Changjiang Estuary. Before construction of the DWP, the lateral straining produced by the interaction between vertical shear in lateral flow and transverse salinity gradient led to rapid development stratification in the water column during the late flood. As a result, the stratification was most developed during the early stage of the ebb tide. Then, the stratification was broken down by vertical mixing and the advection of less stratified water from upstream. The stratification was enhanced after channel narrowing and deepening. In turn, the enhanced stratification altered the vertical velocity profile. The water mass in the upper layer was in a free-stream status, and a strong shear in the velocity occurs since the vertical transfer of momentum was constrained under the pycnocline. As the isopycnal flattened on the upper water column after channel narrowing and deepening, the transverse salinity gradient was mainly driven by differential diffusion, and the magnitude of lateral flow was reduced. Consequently, the along-channel straining and advection became the dominant factor controlling the stratification processes, and the stratification was most developed during the late ebb. The contribution from the lateral straining and advection was minor

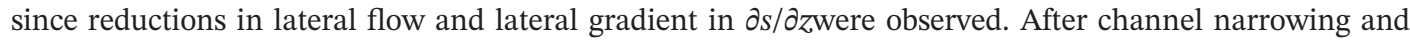
deepening, more sediment tends to be trapped in the turbidity maximum as a result of turbulence suppression. It is quite possible that the excessive sediment in the water column may lead to heavy metal accumulation and reduction of phytoplankton photosynthesis, which becomes a threat to estuarine ecosystem.

\footnotetext{
Acknowledgments

This study was funded by the National Natural Science Foundation of China (51739005), the MOST Project 2016YFE133700, the Fundamental Research Funds for the Central University (42000-31611177), and the Research Project of Shanghai Science and Technology Commission (18DZ1204800, 18DZ1206400). We thank the anonymous reviewers for their constructive comments and suggestions. The numerical modeling codes, input files, and measurement data are available online (https://1drv. $\mathrm{ms} / \mathrm{u} / \mathrm{s}$ !ArUHoh2p4hUgkFpCiT1u3x QwcULM?e=zDGXrw).
}

\section{References}

Allen, J. I., Somerfield, P. J., \& Gilbert, F. J. (2007). Quantifying uncertainty in high-resolution coupled hydrodynamic-ecosystem models. Journal of Marine Systems, 64(1-4), 3-14.

Basdurak, N. B., Valle-Levinson, A., \& Cheng, P. (2013). Lateral structure of tidal asymmetry in vertical mixing and its impact on exchange flow in a coastal plain estuary. Continental Shelf Research, 64, 20-32.

Becherer, J., Stacey, M. T., Umlauf, L., \& Burchard, H. (2015). Lateral circulation generates flood tide stratification and estuarine exchange flow in a curved tidal inlet. Journal of Physical Oceanography, 45, 638-656.

Burchard, H., \& Hofmeister, R. (2008). A dynamic equation for the potential energy anomaly for analysing mixing and stratification in estuaries and coastal seas. Estuarine, Coastal and Shelf Science, 77, 679-687.

Chant, R. J., Sommerfield, C. K., \& Talke, S. A. (2018). Impact of channel deepening on tidal and gravitational circulation in a highly engineered estuarine basin. Estuaries and Coasts, 41(6), 1587-1600. https://doi.org/10.1007/s12237-018-0379-6

Che, Y., He, Q., \& Lin, W. Q. (2003). The distributions of particulate heavy metals and its indication to the transfer of sediments in the Changiiang Estuary and Hangzhou bay, china. Marine Pollution Bulletin, 46(1), 123-131. https://doi.org/10.1016/s0025-326x(02) 00355-7

Chen, J., Li, D., Chen, B., Hu, F., Zhu, H., \& Liu, C. (1999). The processes of dynamic sedimentation in the Changiiang Estuary. Journal of Sea Research, 41(1-2), 140.

Chen, S., \& Sanford, L. P. (2009). Lateral circulation driven by boundary mixing and the associated transport of sediments in idealized partially mixed estuaries. Continental Shelf Research, 29, 101-118.

Chen, W., \& De Swart, H. E. (2016). Dynamic links between shape of the eddy viscosity profile and the vertical structure of tidal current amplitude in bays and estuaries. Ocean Dynamics, 66(3), 299-312.

Cheng, P., Wilson, R. E., Chant, R. J., Fugate, D. C., \& Flood, R. D. (2009). Modeling influence of stratification on lateral circulation in a stratified estuary. Journal of Physical Oceanography, 39, 2324-2337.

Chernetsky, A. S., Schuttelaars, H. M., \& Talke, S. A. (2010). The effect of tidal asymmetry and temporal settling lag on sediment trapping in tidal estuaries. Ocean Dynamics, 60(5), 1219-1241.

De Jonge, V., Schuttelaars, H. M., Beusekom, J., Talke, S. A., \& de Swart, H. E. (2014). The influence of channel deepening on estuarine turbidity levels and dynamics, as exemplified by the ems estuary. Estuarine, Coastal and Shelf Science, 139, 46-59. 
Familkhalili, R., \& Talke, S. A. (2016). The effect of channel deepening on tides and storm surge: A case study of Wilmington, NC. Geophysical Research Letters, 43(17), 9138-9147. https://doi.org/10.1002/2016GL069494

Feng, C., Guo, X., Yin, S., Tian, C., \& Shen, Z. (2017). Heavy metal partitioning of suspended particulate matter-water and sediment-water in the Yangtze Estuary. Chemosphere, 185, 717-725. https://doi.org/10.1016/j.chemosphere.2017.07.075

Field, C. B., Behrenfeld, M. J., Randerson, J. T., \& Falkowski, P. (1998). Primary production of the biosphere: Integrating terrestrial and oceanic components. Science, 281(5374), 237-240. https://doi.org/10.1126/science.281.5374.237

Galperin, B., Kantha, L. H., Hassid, S., \& Rosati, A. (1988). A quasi-equilibrium turbulent energy model for geophysical flows. Journal of the Atmospheric Sciences, 45, 55-62.

Garrett, C., Maccready, P., \& Rhines, P. (1993). Boundary mixing and arrested Ekman layers: Rotating stratified flow near a sloping boundary. Annual Review of Fluid Mechanics, 25(1), 291-323.

Geyer, W. R. (1993). The importance of suppression of turbulence by stratification on the estuarine turbidity maximum. Estuaries, 16, $113-125$.

Geyer, W. R., \& Smith, J. D. (1987). Shear instability in a highly stratified estuary. Journal of Physical Oceanography, 17(10), 1668-1679.

Guo, C., He, Q., Guo, L., \& Winterwerp, J. C. (2017). A study of in-situ sediment flocculation in the turbidity maxima of the Yangtze Estuary. Estuarine, Coastal and Shelf Science, 191, 1-9.

Hamrick, J. M. (1996). User's manual for the environmental fluid dynamics computer code. Gloucester Point, Virginia: Department of Physical Sciences, School of Marine Science, Virginia Institute of Marine Science, College of William and Mary.

Hansen, D. V., \& Rattray, M. (1965). Gravitational circulation in straits and estuaries. Journal of Marine Research, 23, 104-122.

Jeong, S., Yeon, K., Hur, Y., \& Oh, K. (2010). Salinity intrusion characteristics analysis using EFDC model in the downstream of Geum River. Journal of Environmental Sciences (China), 22(6), 934-939. https://doi.org/10.1016/s1001-0742(09)60201-1

Ji, Z. G., Morton, M. R., \& Hamrick, J. M. (2001). Wetting and drying simulation of estuarine processes. Estuarine, Coastal and Shelf Science, $53,683-700$.

Jiang, C., Li, J., \& de Swart, H. E. (2012). Effects of navigational works on morphological changes in the bar area of the Yangtze Estuary. Geomorphology, 139-140, 205-219.

Kuo, A. Y., \& Neilson, B. J. (1987). Hypoxia and salinity in Virginia estuaries. Estuaries, 10(4), 277-283.

Lerczak, J. A., \& Geyer, W. R. (2004). Modeling the lateral circulation in straight, stratified estuaries. Journal of Physical Oceanography, 34 $1410-1428$.

Li, L., Wu, H., Liu, J. T., \& Zhu, J. (2015). Sediment transport induced by the advection of a moving salt wedge in the Changjiang Estuary. Journal of Coastal Research, 31(3), 671-679.

Li, M., Cheng, P., Chant, R., Valle-Levinson, A., \& Arnott, K. (2014). Analysis of vortex dynamics of lateral circulation in a straight tidal estuary*. Journal of Physical Oceanography, 44, 2779-2795.

Li, X., Geyer, W. R., Zhu, J., \& Wu, H. (2018). The transformation of salinity variance: A new approach to quantifying the influence of straining and mixing on estuarine stratification. Journal of Physical Oceanography, 48, 607-623.

Lin, J., \& Kuo, A. Y. (2003). A model study of turbidity maxima in the York River Estuary, Virginia. Estuaries, 26, 1269-1280.

Liu, G., Zhu, J., Wang, Y., Wu, H., \& Wu, J. (2011). Tripod measured residual currents and sediment flux: Impacts on the silting of the Deepwater Navigation Channel in the Changiiang Estuary. Estuarine, Coastal and Shelf Science, 93, 192-201.

Liu, H., He, Q., Wang, Z., Weltje, G. J., \& Zhang, J. (2010). Dynamics and spatial variability of near-bottom sediment exchange in the Yangtze Estuary, China. Estuarine, Coastal and Shelf Science, 86(3), 322-330.

Mellor, G. L., \& Yamada, T. (1982). Development of a turbulence closure model for geophysical fluid problems. Reviews of Geophysics, 20 , 851-875.

Monismith, S. G. (2010). In A. Valle-Levinson (Ed.), Mixing in estuaries. Contemporary Issues in Estuarine Physics (pp. 145-185). Cambridge: Cambridge University Press.

Murphy, A. H. (1988). Skill scores based on the mean square error and their relationships to the correlation coefficient. Monthly Weather Review, 116(12), 637-649.

Nepf, H. M., \& Geyer, W. R. (1996). Intratidal variations in stratification and mixing in the Hudson estuary. Journal of Geophysical Research, $101,12079-12086$.

Niroomandi, A., Ma, G., Su, S. F., Gu, F., \& Qi, D. (2018). Sediment flux and sediment-induced stratification in the Changjiang Estuary. Journal of Marine Science and Technology, 23(2), 349-363. https://doi.org/10.1007/s00773-017-0478-2

Nunes, R. A., \& Simpson, J. H. (1985). Axial convergence in a well-mixed estuary. Estuarine, Coastal and Shelf Science, $20,637-649$.

Oke, P. R., Allen, J. S., Miller, R. N., Egbert, G. D., Austin, J. A., \& Barth, J. A. (2002). A modeling study of the three-dimensional continental shelf circulation off Oregon. Part I: Model data comparisons. Journal of Physical Oceanography, 32(5), 1360-1382.

Pan, L., Ding, P., \& Ge, J. (2012). Impacts of deep waterway project on morphological changes within the north passage of the Changjiang Estuary, China. Journal of Coastal Research, 284(5), 1165-1176.

Park, K., Jung, H. S., Kim, H. S., \& Ahn, S. M. (2005). Three-dimensional hydrodynamic-eutrophication model (HEM-3D): Application to Kwang-Yang Bay, Korea. Marine Environmental Research, 60(2), 171-193. https://doi.org/10.1016/j. marenvres.2004.10.003

Perillo, G. M. E., Pérez, D. E., Piccolo, M. C., Palma, E. D., \& Cuadrado, D. G. (2005). Geomorphologic and physical characteristics of a human impacted estuary: Quequén Grande River Estuary, Argentina. Estuarine, Coastal and Shelf Science, 62, 301-312.

Peters, H., \& Bokhorst, R. (2000). Microstructure observations of turbulent mixing in a partially mixed estuary. Part I: Dissipation rate. Journal of Physical Oceanography, 30, 1232-1244.

Pu, X., Shi, J. Z., Hu, G., \& Xiong, L. (2015). Circulation and mixing along the North Passage in the Changjiang River estuary, China. Journal of Marine Systems, 148, 213-235.

Scully, M. E., \& Freidrichs, C. T. (2007). The importance of tidal and lateral asymmetries in stratification to residual circulation in partially mixed estuaries. Journal of Physical Oceanography, 37, 1496-1511.

Scully, M. E., \& Geyer, W. R. (2012). The role of advection, straining, and mixing on the tidal variability of estuarine stratification. Journal of Physical Oceanography, 42, 855-868.

Simpson, J. H. (1981). The shelf-sea fronts: Implications of their existence and behaviour. Philosophical Transactions. Royal Society of London, 531-546.

Simpson, J. H., Brown, J., Matthews, J., \& Allen, G. (1990). Tidal straining, density currents, and stirring in the control of estuarine stratification. Estuaries, 13, 125-132.

Soulsby, R. L. (1983). The bottom boundary layer of shelf seas. In Physical Oceanography of Coastal and Shelf Seas (pp. 189-266). Netherlands: Elsevier. https://doi.org/10.1016/S0422-9894(08)70503-8 
Souza, A. J., \& Simpson, J. H. (1996). The modification of tidal ellipses by stratification in the Rhine ROFI. Continental Shelf Research, 16 , 997-1007.

Souza, A. J., \& Simpson, J. H. (1997). Controls on stratification in the Rhine ROFI. Journal of Marine Systems, 12, 311-323.

Stacey, M. T., \& Ralston, D. K. (2005). The scaling and structure of the estuarine bottom boundary layer. Journal of Physical Oceanography, $35,55-71$.

Talke, S. A., Swart, H. E. D., \& Jonge, V. N. D. (2009). An idealized model and systematic process study of oxygen depletion in highly turbid estuaries. Estuaries and Coasts, 32(4), 602-620.

Visser, A. W., Souza, A. J., Hessner, K., \& Simpson, J. H. (1994). The effect of stratification on tidal current profiles in a region of freshwater influence. Oceanolofica Acta, 17, 369-381.

Wang, Y., Shen, J., \& He, Q. (2010). A numerical model study of the transport timescale and change of estuarine circulation due to waterway constructions in the Changjiang Estuary, China. Journal of Marine Systems, 82, 154-170.

Winterwerp, J. C. (2011). Fine sediment transport by tidal asymmetry in the high-concentrated Ems river: Indications for a regime shift in response to channel deepening. Ocean Dynamics, 61(2-3), 203-215.

Wu, H., Zhu, J., \& Ho Choi, B. (2010). Links between saltwater intrusion and subtidal circulation in the Changjiang Estuary: A modelguided study. Continental Shelf Research, 30, 1891-1905.

Yin, S., Wu, Y., Xu, W., Li, Y., Shen, Z., \& Feng, C. (2016). Contribution of the upper river, the estuarine region, and the adjacent sea to the heavy metal pollution in the Yangtze Estuary. Chemosphere, 155, 564-572. https://doi.org/10.1016/j.chemosphere.2016.04.095

Zaikowski, L., Mcdonnell, K. T., Rockwell, R. F., \& Rispoli, F. (2008). Temporal and spatial variations in water quality on New York south shore estuary tributaries: Carmans, patchogue, and swan rivers. Estuaries and Coasts, 31(1), 85-100.

Zhu, L., He, Q., \& Shen, J. (2018). Modeling lateral circulation and its influence on the along-channel flow in a branched estuary. Ocean Dynamics, 68, 177-191.

Zhu, L., He, Q., Shen, J., \& Wang, Y. (2016). The influence of human activities on morphodynamics and alteration of sediment source and sink in the Changjiang Estuary. Geomorphology, 273, 52-62. 